\title{
Manisa Büyükşehir Belediyesi Merkez İlçeler Meclis Üyelerinin Katılımcı Bütçe Uygulamasına Yönelik Görüş ve Tutumlarına Dair Bir Araştırma*
}

\section{A Research on the Opinions and Attitudes of Participatory Budget Applications of Manisa Metropolitan Municipality Central District Council Members}

\author{
Gözde Doğan ${ }^{1}$ \\ Güneş Çetin Gerger²
}

EMPIRICAL

RESEARCH

\section{ARTICLE INFO}

Submitted : 06.09.2018

Revised : 17.10.2018

Accepted : 05.12.2018

Available : 30.12 .2018

JEL classification:

$\mathrm{H} 11, \mathrm{H} 19, \mathrm{H} 83$

Keywords:

Government Budget, Local Administration, Governance,

Participatory Budget

\begin{abstract}
A B S T R A C T
Modern budget systems have existed since the 1980s. Local government budgets include citizen demand and citizen participation, which are conceptualized in modern budget systems. Governance and participatory budget practices support active citizenship practices in local government budgets. Participatory budgeting is observed in many countries of the world. The first participatory budget was implemented in Porto Alegre, Brazil. It is stated that participatory budget implementation in Porto Alegre has been a pattern for other countries in the world. In this study, examples of New York and India are included. Çanakkale Municipality is the only official participatory budgeting pilot application in Turkey. In this study, after the conceptual framework of the participatory budget is described, Manisa Metropolitan Municipality central districts members's opinions and attitudes will be covered. In the research, semi-structured interview method was conducted.
\end{abstract}

Cite this article as: Doğan, G. \& Çetin Gerger, G. (2018). “Manisa Büyükşehir Belediyesi Merkez İlçeler Meclis Üyelerinin Katılımcı Bütçe Uygulamasına Yönelik Görüş ve Tutumlarına Dair Bir Araştırma", International Journal of Public Finance, Vol.3, No.2, pp. 205-231.

\footnotetext{
* This paper was derived from the study which was accepted as a master thesis in Manisa Celal Bayar University, Institute of Social Sciences on 20 April 2018.

1 Independent researcher, (ORCID ID: https://orcid.org/0000-0001-5488-3417) Manisa Celal Bayar University, gozdedoğan1991@gmail.com

2 Assoc. Prof., PhD., (ORCiD ID: https://orcid.org/0000-0002-5823-7866), Manisa Celal Bayar University, gunes.cetin@hotmail.com
} 
Doğan, G. \& Çetin Gerger, G. (2018). “Manisa Büyükşehir Belediyesi Meclis Üyelerinin Katılımcı Bütçe

Uygulamasına Yönelik Görüşleri”, International Journal of Public Finance, Vol.3, No.2, pp. 205-231.

\section{MAKALE BİGisi \\ Gönderme: 06.09.2018 \\ Düzeltme : 17.10 .2018 \\ Kabul : :05.12.2018 \\ Yayın : $: 30.12 .2018$}

\section{JEL Kodu:}

$\mathrm{H} 11, \mathrm{H} 19, \mathrm{H} 83$

\section{Anahtar Kelimeler:}

Devlet Bütçesi, Yerel Yönetimler, Yönetişim, Katılımcı Bütçe

\begin{abstract}
ÖZET
Modern bütçe sistemleri 1980'li yıllardan günümüze kadar varlığını sürdürmektedir. Yerel yönetim bütçeleri de modern bütçe sistemlerinde kavramsallaşan vatandaş talebi ve vatandaş katılımına yer vermektedir. Yönetişim ve katılımcı bütçe uygulamaları yerel yönetim bütçelerinde aktif vatandaşlık uygulamalarını desteklemektedir. Dünyanın birçok ülkesinde katılımcı bütçe uygulaması görülmektedir. Katılımcı bütçe uygulaması dünyada ilk kez Brezilya'nın Porto Alegre kentinde görülmüştür. Porto Alegre'deki katılımcı bütçe uygulamasının diğer dünya ülkelerine de örnek olduğu ifade edilmektedir. Bu çalışmada, Newyork ve Hindistan örnekleri yer almaktadır. Türkiye'de tek resmi katılımcı bütçe pilot uygulaması ile Çanakkale Belediyesi katılımcı bütçe uygulaması karşımıza çıkmaktadır. Bu çalışmada katılımcı bütçenin kavramsal çerçevesi çizildikten sonra Manisa Büyükşehir Belediyesi merkez ilçeler meclis üyelerinin katılımcı bütçe konusunda görüş ve tutumlarına yer verilecektir. Araştırmada yarı yapılandırılmış görüşme yöntemi gerçekleştirilmiştir.
\end{abstract}

\section{Giriş}

21.yüzyılda yeni kamu yönetimi anlayışı ile şekillenen katılımcı bütçe kavramı karşımıza çıkmaktadır. Katılımcı bütçe kavramının yerel yönetimlere uygun modern bütçeleme yöntemi olduğu uzmanlarca ifade edilmektedir. Yerel idarelerde katılımcılık iki şekilde gerçekleşmektedir. Bunlardan ilki siyasi seçim sürecinde aktif rol oynayıp oy verme ile vatandaşın kendi siyasi görüşünü temsil eden kişi ya da kişileri seçme hakkıdır. İkincisi ise vatandaşın dolaylı şekilde yerel yönetim plan ve projelerinde yer alarak, bunlar konusunda fikir beyan etmesiyle gerçekleşmektedir.

Bu çalışmada Manisa'da ilk kez, katılımcı bütçe konusunda merkez ilçeler meclis üyeleri ile görüşme tekniğine dayanan bir araştırma gerçekleştirilmiştir. Manisa Merkez Illçeler Meclis üyelerine yarı yapılandırılmış görüşme yöntemi kullanılarak birtakım sorular sorulmuştur. Çalışmada, Manisa Büyükşehir Belediyesi Merkez İlçeler Meclis Üyeleri ile gerçekleştirilen katılımcı bütçe görüşme sorularının sonuçları değerlendirilmiştir.

Çalışmanın ilk bölümünde katılımcı bütçe kavramı, tarihsel süreci, katılımcı modelin işleyişi ifade edilmektedir. İkinci bölümde yarı yapılandırılmış görüşme yönteminde verilerin toplanması, verilerin güvenilirliği ve verilerin analizi yer almaktadır. Buna ek olarak görüşme sonucu elde edilen bulgular başlıklar halinde sınıflandırılıp ifade edilmektedir.

\section{Katılımcı Bütçe Kavramı}

Bütçe, etimolojik kökeni Latince 'bulga' sözcüğünden türemiştir. Kavramın karşılığı Fransızca' da 'bougette' kelimesi ile ifade edilmektedir. Bütçe kavramı, İngilizce' de 'budget' ya da 'balance' olarak ifade edilmektedir. Sözcük, Almanca' da 
'haushaltplan' ya da 'soll' olarak karşılık bulmuştur. Genelde 'budget' sözcüğü kullanılagelmiştir (Nihat Falay, 2003: 3). Kamu kesiminin, gelecek bir dönem için kaynaklarının harcama dengesini ifade eden ve özellikle parlamenter demokrasilerde yasama organının yürütme organına kamu harcamasını gerçekleştirme ve kamu gelirlerini toplama konusunda vermiş olduğu yetkiyi açık bir şekilde gösteren belgeye devlet bütçesi denilmektedir (Ömer Faruk Batırel, 1990: 1).

Katılımcı bütçe kavramı, bütçe hakkı sayesinde devlet bütçesinin katılımcı esaslarla yürütülmesini ifade etmektedir. Katılımcı bütçe kavramı, katılım ve bütçe faaliyetleri ile ilişkilidir. Katılımcı bütçe kavramının orijinal adı Portekizce Orçamento Participativo' dur. Kavram, 1990'lı yıllardan itibaren dünya ülkelerinde ilgi çekmeye başlamıştır. Demokratik unsurların ön planda olduğu bütçeleme yapısını ifade etmektedir (Ahmet Özen \& Ibrahim Güray Yontar, 2009: 283). Bir diğer tanımla, katılımcı bütçe, katılımcı demokrasi ile özdeşleşerek karşımıza çıkmaktadır. Katılımcı demokrasi, yerelleşme süreci içinde karar alma eylemlerinde yeni bir boyuttur. Yerel yönetimlerde, katılımcı bütçe faaliyetleri sayesinde vatandaş bütçe görüşmelerine ya da kamu kaynaklarının tahsisinde direkt ve bağımsız -bir birey- olarak katılabilmektedir (Süreyya Sakınç \& Sibel Aybarç Bursalıoğlu, 2014: 2). Katılımcı bütçe, yerel yönetim birimlerinin yerel halkın katılımı doğrultusunda oluşturulan bir bütçeleme sürecini ifade etmektedir. Katılımcı bütçe süreci, yerel halkın ihtiyaçlarına göre ölçeklendirilen harcamaların belirlendiği bir süreç olarak da ifade edilmektedir (TEPAV, 2007: 2).

\subsection{Katılımcı Bütçenin Tarihsel Süreci}

Katılımcı bütçe uygulamasını içinde bulunduğu şartlar itibari ile bir ihtiyaç olarak gören Brezilya, dünyada katılımcı bütçenin ilk resmi örneğini gerçekleştirmiştir. Ülkede 1988 yılında yeni kabul edilen federal yasa ile mali özerklikler tanınan eyaletlerin kapsam bakımından âdem-i merkeziyetçi yapıya bürünmesi ile birlikte halkın katılımının önü açılmıştır. Brezilya'nın Porto Alegre kentinde ülke anayasalarında "bütçe yönlendirilmesinin her aşamasında halkın katılımının gerekliliği" ifadesi yer almaktadır (Leonardo Avritzer, 2000: aktaran Yavuz Yıldırım, 2008: 28). Bu anlamda, Brezilya'da 1990'lı yıllarda katılımc bütçenin etkin bir şekilde uygulanmaya başladığı görülmüştür (Zuhal Ergen, 2012: 325). Brezilya dışında Avrupa'da da katılımcı bütçe uygulamaları görülmektedir. Bu ülkelerden bazıları, 1994 yılında İtalya'da Grottammare kenti, 1996 yılında İngiltere'de Salford kenti, 1998 yılında Almanya'da Monchweiler kenti olarak sayılmaktadır (Sakınç \& Aybarç Bursalıoğlu, 2014: 5).

Günümüzde, katılımcı bütçe uygulamaları bilişim yönetim sistemleri ile geliştirilmeye çalışılmaktadır. Teknoloji ile bütçe kavramı, e-bütçeleme sistemini de beraberinde getirmiştir. Dünyada ve Türkiye'de e-bütçeleme ve dijital bütçeleme sistemleri konusunda çalışmalar ve projeler yürütülmektedir. Katılımcı bütçe yaklaşımında yeni bir boyut olan PB Unit Participatory Budgeting Unit katılımcı bütçe birimi anlamına gelen yaklaşımdır. KBB, sosyal medya, kamu katılımı ve sivil toplum ayağı ile gerçekleştirilmektedir. Böylece katılımcı bütçelemenin uygulama alanı genişlemekte ve aynı zamanda kamu yönetimi açısından meşruiyet sağlanmaktadır. 
Uygulama alanı İngiltere olan KBB' de bütçe katılımı online görüşmeler ile gerçekleştirilmektedir. Bu uygulamanın kamu kaynakları açısından faydası ise maliyet tasarrufları sağlaması, yerel yönetimlerin en düşük maliyete katlanarak kaynakların optimum kullanımını gerçekleştirebilmesidir (Cumhur Dülger, 2013: 105). Burada esas düşünce toplumu standartlaşmadan kurtarmaktır. Türkiye'de dijital katılımcı yönetim uygulamasında en güncel örnek ise İstanbul'da görülmüştür. Örneğin, "Haydi İstanbul Vapurunu Seç" kampanyası gibi belediyeye alınacak taşıtların renk ve model seçimi, belediye ihtiyacına yönelik seçim yapılması gibi uygulamalar söz konusu olmuştur (https://www.dijitaldonusum.gov.tr/karar-mekanizmalari/, 2018).

\subsection{Katılımcı Bütçenin İlk Örneği; Porto Alegre}

Yerel yönetimlerde dünyanın ilk "katılımcı bütçe" uygulaması Brezilya'da Rio De Grande Do Sol eyaletinin başkenti olan Porto Alegre'de görülmüştür. Bu uygulama, yerel idare tarafından kentte yoksullaşmanın artması ve kaynak kullanımında etkinsizlik sebebiyle uygulanmaya başlanmıştır (Özhan Çetinkaya \& Rükan Kutlu Korlu, 2012: 99). Porto Alegre'de katılımcı bütçe uygulaması 1989 yılında belediye başkanı Olivio Dutra yönetiminde başlatılmıştır. 1990 yılında kent bütçesinde ise fiili olarak uygulamaya geçilmiştir (Sonay Bayramoğlu, 2015: 134).

Brezilya'da 1989'da gerçekleştirilen yerel seçimler sonrasında İşçi Partisi'nin seçimleri kazanmasıyla Porto Alegre' de katılımcı bütçe uygulamasını başlattığı gibi bu partinin kazanmış olduğu diğer eyaletlerde de uygulanmaya başlamıştır. Böylece belediye yönetimi, karar alma süreçlerinde özellikle yoksul ve dezavantajlı kesimlerin kamu politikaları içinde söz sahibi olmasını da desteklemiştir. Bu anlamda halk, bütçe politikalarının gerçekleştirilmesinde doğrudan söz sahibi olabilmiştir(Sakınç \& Aybarç Bursalıoğlu, 2014: 3). Katılımcı bütçe modelleri ülkeden ülkeye ve kentten kente farklılık gösterebilmektedir.

\subsection{Porto Alegre Katılımcı Modelin İşleyişi}

Porto Alegre katılımcı bütçe modelinde halkın doğrudan ya da doğrudan olmaksızın gerçekleştirdiği katılım programı, kamu projeleri için fikir beyan etmesi şeklindedir. Porto Alegre'de yerel halkın katılımıyla oluşturulan mahalle toplantıları ve daha geniş kesimi içine alan semt bazlı toplantılar yapılmaktadır. Burada kente dair sorunlar ya da kent gelişimi için varsa öneriler görüşülüp tartışılmaktadır. Yeni bir öneri ya da kararın ifade edilmesi hususunda katılımcılar aralarında temsilciler seçmektedirler. Temsilciler aracılığı ile görüş ve öneriler Belediye Bütçe Konseyi'ne sunulmaktadır. Mahalle toplantıları ve semt bazlı toplantıların yanında tematik toplantılar da gerçekleştirilmektedir. Tematik toplantılar, isminden belli olduğu üzere belli bir tema, belli bir konu için gerçekleştirilen halkın toplantılarıdır ve toplanmanın konusu bellidir (Yavuz Yıldırım, 2008: 283). Bu toplantılar tematiktir ve genelde beş tema üzerinde durulmaktadır. Bunlar, ulaşım, eğitim ve kültür, sağlık ve sosyal refah, ekonomik gelişme ve vergilendirme, kentsel gelişim ve şehir düzenidir (De Sousa Santos, 1998:2 aktaran Wagle\& Shah, 2003: 2). Katılımcı bütçe sürecinde yer alan 
kesimler üç grupta sınıflandırılmaktadır. Birinci grup belediye idare birimlerinden, ikinci grup halk organizasyonları birliklerinden üçüncü grup ise bu iki grup arasında eş güdüm ve iletişim kuran gruplardan oluşmaktadır (De Sousa Santos, 1998: 468-469).

Şekil 1.Katılımcı Bütçe Sürecinde Yer Alan Gruplar

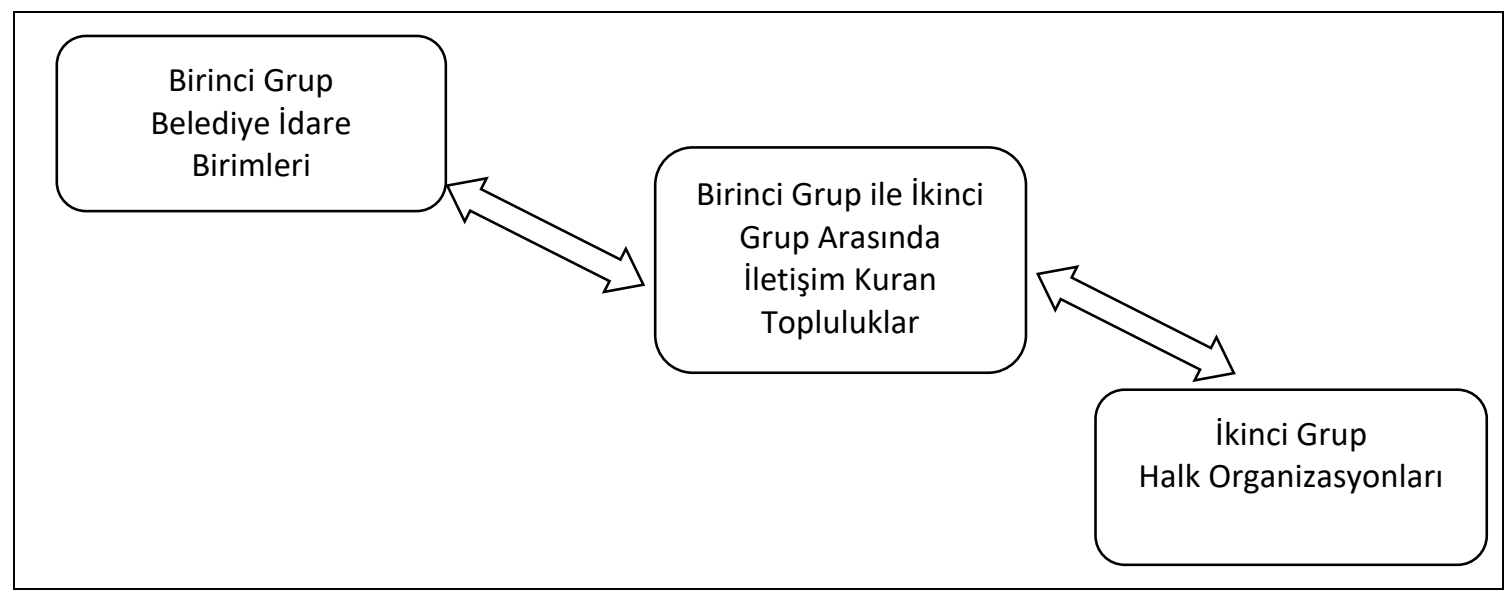

Kaynak: Boaventura de Sousa Santos, "Participatory Budgeting in Porto Alegre: Toward a Redistributive Democracy", Politics \& Society, Volume 26, December, 1998, ss.468-469'dan derlenerek tarafımca şekillendirilmiştir.

Şekil 1'e göre, Porto Alegre modelinde yer alan birinci grup idareler, belediye tarafından oluşturulan ve katılımcı bütçe sürecinin görüşmelerini takip eden birimlerdir. Katılımcı bütçe birinci grup idarelerde altı adet birim bulunmaktadır. Katılımcı bütçe sürecini idare eden bu birimler şunlardır(Santos, 1998: 468); Planlama Komitesi olarak ifade edilen GAPLAN (Gabinete de Planejamento- Planning Office) katılımcı bütçe görüşmelerinin teknik düzenlemelerini yapmaktadır. GAPLAN, katılımcı bütçe sürecinde yerel halkın isteklerini değerlendirip ekonomik incelemelerde bulunmaktadır. Bu grup karar almada önemli bir yere sahiptir. İkinci birim Topluluklarla Ilişkiler Koordinasyonu olarak ifade edilen CRC (Coordination of Relations with the Communities), katılımcı bütçenin idari düzeninden sorumlu tutulmaktadır. Üçüncü birim ise Planlama Danışmanları Kurulu olarak ifade edilen ASSEPLAS ( Forum of Advisors for Planning)'tır. Dördüncü birim Halk Danışmaları Kurulu olarak ifade edilen FASCOM (Forum of Community Advisors), beşinci birim, Katılımcı Bütçe Bölge Koordinatörü olarak ifade edilen CROPs ( Regional Coordinators of the Participatory Budgeting) vatandaşlarla iletişim bağını güçlü tutmak adına faaliyetler gerçekleştirmektedir. Altıncı birim, Tematik Koordinatörler olarak ifade edilen CTs (Thematic Coordinators), halkın katılım sağladığı her tematik toplantıya rehberlik etmektedir. Bu birimler katılımcı bütçe sürecinin temel kurumları olarak ifade edilmektedir.

Katılımcı bütçe sürecinde ikinci grup olarak adlandırılan gruplar üç birimden oluşmaktadır ve halk organizasyonları şeklindedir. Daha çok yüz yüze görüşmeler gerçekleştirilmektedir. Bunlar, halk konseyleri olarak ifade edilen PC (Popular Councils), 
Bucak birlikleri olarak ifade edilen TU (Township Unions) ve Bölge birlikleri olarak ifade edilen RA (Region Articulations)'dır. Katılımcı bütçe sürecinde üçüncü grup ise birinci ve ikinci grup arasında ara buluculuk görevi üstlenen kesimdir. Üçüncü grup, altı birimden oluşmaktadır. Bunlar şöyle ifade edilmektedir; Katılımcı Bütçe Konseyi (COP; Conselho do Orçamento Participativo- Participatory Budgeting Council), Bölgesel Genel Meclisler (Regional Plenary Assemblies), Bütçeleme Bölge Toplantıları (Budgeting Regional Forum), Tematik Genel Meclisler (Thematic Plenary Assemblies), Bütçeleme Tematik Forumu (Budgeting Thematic Forum) (Santos, 1998: 469).

Katılımcı bütçe konseyine (COP); Tematik meclis, Mahalleler Birliği, Belediye Çalışanları Sendikası, Belediye Yönetim Planlama Komisyonu, Toplumsal illişkiler Koordinasyonu temsilciler göndermektedir. Katılımcı Bütçe Konseyi, bahsedilen temsilcileri ile birlikte periyodik aralıklarla toplanmaktadır ve bünyesinde yer alan verileri belediye yönetimine sunmaktadır. Bununla birlikte bir önceki dönem bütçesinin tartışılması ve gelecek yıl bütçesinin genel hatlarının belirlenmesi bu konseyin görev ve amaçları arasındadır (Avritzer, 2000: aktaran Yıldırım,2008: 283). Katılımcı Bütçe Konseyi, çeşitli komisyonlarca oluşturulan fikirleri bütçe taslağı formuna getirmektedir (Ergen, 2012: 327). Porto Alegre, büyük ve kalabalık bir şehir olduğu için bütçe süreci profesyonel bir örgütlenmeyi beraberinde getirmektedir. Kent yönetimi bu uygulamayı Porto Alegre' de siyasetten uzaklaşıp demokrasi uygulamaları ile yoğrulan ve yönetilenyöneten ayrımının yapılmadığı bir deneyim olarak değerlendirmektedir (Yıldırım, 2008: 284). Şekil 2'de katılımcı bütçe süreci özetlenmektedir.

\section{Şekil 2. Yıllık Katılımcı Bütçe Süreci}

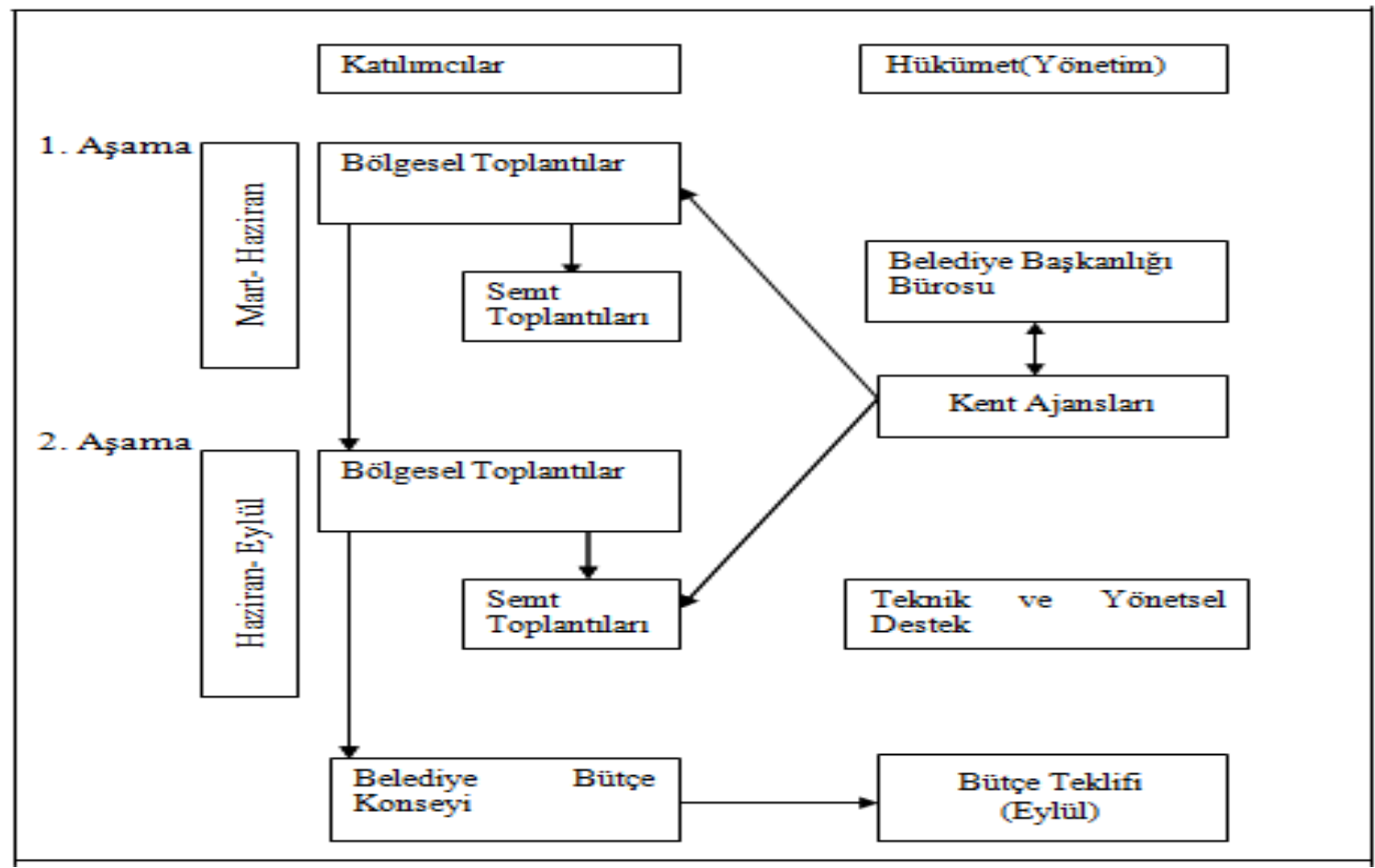

Kaynak: Brain Wampler, Participatory Budgeting in Brazil, The Pennsylvania State University Press University Park, Pennsylvania, 2007, s.53. 
Şekil 2'de, katılımcı bütçe sürecinde ilk tura kadar olan sürede katılımcıların rolleri ve hükümetin temel görevi ifade edilmektedir. Illk tur, Mart ayından Haziran'a kadar devam etmektedir. Bu süreçte kamu politikaları üzerine ilk tartışmalar gerçekleşmektedir. Toplantılarda seçilen temsilci sayısının belirlenmesi ile ilgili bilgiler dağıtılmaktadır. Özellikle mahalle düzeyindeki toplantılarda mahalleden seçilen temsilcinin bir projenin kabul edilme ihtimalini arttırdığı düşünülmektedir. Bölgesel ve mahalle düzeyindeki toplantılar yaklaşık olarak iki saat sürebilmektedir. Toplantının ilk aşamasında katılımcılara yaklaşan etkinlikler ve güncel konularla ilgili güncel veri akışını sağlama imkânı verilmektedir. İkinci aşamasında resmi görevlilerin sunumu gerçekleşmektedir, son bölüm ise soru cevap şeklindedir. Katılımcılara hükümet görevlileri ile konuşmak ya da onlara soru sormak için üç dakikalık zaman dilimi verilmektedir. Bu süre toplantının hızını korumaya yardımcı olmaktadır. Toplantıda öncelikler belirlenmekte ve hükümet görevlileri, katılımcılar ile birlikte çalışmaktadır. Temel toplantı gündemi katılımda gönüllülük esası ile devam ettirilmektedir. Vatandaşlar sürecin kurallarına uyum sağlayarak daha etkin bir katılımcı bütçe sürecini gerçekleştirebilmek için özveride bulunmaktadırlar. Mart ayından Haziran ayına kadar olan süreçte hükümetin ve katılımcıların rolü tablo 1'de özetlenmektedir(Brain Wampler, 2007: 54-55).

Tablo 1. Mart ve Haziran Ayı Bölgesel Görüşmelerde Katılımcı Bütçe Süreci

\begin{tabular}{|l|l|}
\hline Hükümet'in Rolü & Katılımcıların Sorumlulukları \\
\hline Bucak ve bölge sınırlarını belirler. & Vatandaşları katılım için harekete geçirir. \\
\hline Yaşam kalitesi endeksini hazırlar. & Toplantılar yoluyla kapasite oluşturur. \\
\hline Mali kaynak bilgileri dağııı. & Mali bilgilerin analizini izler. \\
\hline $\begin{array}{l}\text { Katılımcılar tarafından uygulanmak üzere } \\
\text { arzulanan ve kabul edilen projeleri sunar. }\end{array}$ & $\begin{array}{l}\text { Mevcut kaynaklar hakkında müzakereye } \\
\text { sahiptir. }\end{array}$ \\
\hline
\end{tabular}

Kaynak: Wampler, s.54.

Tablo 1'de görüldüğü üzere Mart ayından Haziran ayına kadar olan süreçte bölgesel anlamda yürütme organının müdahalesi olmaksızın vatandaşlar katılım için harekete geçmektedir. Bu evrede kente dair bilgilerin toplanmaktadır. Katılımcı vatandaşlar ile hükümet arasındaki iletişimin ve etkileşimin sağlıklı gerçekleştirilmesi için her iki taraf da katılımcı bütçe sürecine hazırlık yapmaktadır (Wagle \& Shah, 2003: 2). Mart ayından Haziran ayına kadar mahalle görüşmelerinde katılımcı bütçe süreci tablo 2'te özetlendiği gibi gerçekleşmektedir. 
Doğan, G. \& Çetin Gerger, G. (2018). “Manisa Büyükşehir Belediyesi Meclis Üyelerinin Katılımcı Bütçe

Uygulamasına Yönelik Görüşleri”, International Journal of Public Finance, Vol.3, No.2, pp. 205-231.

Tablo 2. Mart ve Haziran Ayı Mahalle Görüşmelerinde Katılımcı Bütçe Süreci

\begin{tabular}{|l|l|}
\hline Hükümet'in Rolü & Katılımcıların Sorumlulukları \\
\hline Ayrıntılı teknik bilgi sağlar. & Belediyeler için öncelikleri müzakere eder. \\
\hline $\begin{array}{l}\text { Katılımın desteklenmesi için bürokratik } \\
\text { destek sağlar (Telefon görüşmeleri, } \\
\text { bilgilendirme broşürleri...). }\end{array}$ & Belirli kamu işlerini müzakere eder. \\
\hline Görüşme zamanlarını ve yerlerini belirler. & Kamu işlerinin ön seçimini gerçekleştirir. \\
\hline
\end{tabular}

Kaynak: Wampler, s.54.

Katılımcı bütçenin birinci evresi olarak değerlendirilen Mart ayından Haziran ayına kadar olan süreçte hem bir önceki yılın bütçe uygulamaları hem de süregelen yatırımlar hakkında belediye görevlileri halka bilgi sunmaktadır (Bkz. Tablo 2). Birinci evrede, halkın görüş ve önerilerinin ya da eleştirilerinin ifade edildiği bir süreçtir. Bu evre bir sonraki yıl için bütçe çalışmalarının başlangıç evresi sayılmaktadır (Ergen, 2012: 324).

íkinci tura bakıldığında hükümet, önündeki mali yıl için (iki-üç yıllık da olabilir) uygulayacağı politikaları ve projeleri tanımlamaktadır. Bu sırada katılımcılar, toplumun önceliklerini ifade etmek için yeterli bilgi toplamaktadırlar. Belirli kamu işleri ve projeleri için nihai kararların verilebilmesi amacı ile bölgesel toplantılar gerçekleştirilmektedir. Birinci ve ikinci tur arasında "Csos Turları" denen tur stratejilerini planlamak için mahalle düzeyinde yaygın toplantılar yapılmaktadır. Burada amaç toplumda söz sahibi olamayan dezavantajlı insanların seslerini duyurabilmektir. Bununla birlikte kentin kalkınması ve gelişmesi için gerekli olan yatırım önceliklilerinin belirlenmesidir (Wagle \& Shah, 2003: 5). İkinci turu ifade eden Haziran ayından Kasım ayına kadar olan süreçte hükümetin ve katılımcıların katılımcı bütçe sürecinde hangi yollardan geçtiği tablo 3 ve 4 'te özetlenmektedir.

Tablo 3.Haziran ve Kasım Ayı Bölgesel Görüşmelerde Katılımcı Bütçe Süreci

\begin{tabular}{|c|c|}
\hline Hükümet'in Rolü & Katılımcıların Sorumlulukları \\
\hline $\begin{array}{l}\text { Önerilen projeler için maliyetlerin başlangıç } \\
\text { tahminlerini sunar. }\end{array}$ & $\begin{array}{l}\text { Önerilen politika, proje ya da kamu } \\
\text { çalışmalarını tartışır. }\end{array}$ \\
\hline $\begin{array}{l}\text { Her bölgede "öncelikli keşif" amacının } \\
\text { gerçekleştirilmesi için bilgilendirme ve } \\
\text { düzenleme gerçekleştirir. }\end{array}$ & $\begin{array}{l}\text { "Öncelikli keşif" amacına uygun olarak kamu } \\
\text { projeleri için saha ziyaretleri gerçekleştirir. }\end{array}$ \\
\hline Oyları izler. & $\begin{array}{l}\text { Uygulanacak kamu politikalarına veya kamu } \\
\text { çalışmalarına oy verir. }\end{array}$ \\
\hline Belediye bütçe konseyini denetler. & $\begin{array}{l}\text { Her bölge belediye bütçe konseyine iki } \\
\text { temsilci seçer. }\end{array}$ \\
\hline
\end{tabular}

Kaynak: Wampler, s.56. 
Haziran ve Kasım ayı bölgesel görüşmelerde katılımcı bütçe süreci tüm hızıyla devam etmektedir (Tablo 3). Burada esas konu kaynakların kullanımında dikkat edilecek unsurlardır. Eylül ayı itibari ile yeni bütçe Katılımcı Bütçe Konseyi (COP) tarafından tartışılıp onaylanması için yasama organı olan meclise gönderilmektedir (Wagle \& Shah, 2003: 5). Haziran-Kasım ayı mahalle görüşmelerinde katılımcı bütçe süreci tablo 4 'te özetlenmektedir.

Tablo 4.Haziran ve Kasım Ayı Mahalle Görüşmelerinde Katılımcı Bütçe Süreci

\begin{tabular}{|l|l|}
\hline Hükümetin Rolü & Katılımcıların Sorumlulukları \\
\hline $\begin{array}{l}\text { Teknik personel gözetim komiteleri ile } \\
\text { yakından çalışır. }\end{array}$ & $\begin{array}{l}\text { Projeler ve politikalar için katılımı artırıcı } \\
\text { unsurlar geliştirir. }\end{array}$ \\
\hline Teknik planların taslaklarını oluşturur. & $\begin{array}{l}\text { Seçilen gözetim komiteleri üyeleri teknik } \\
\text { planları onaylar. }\end{array}$ \\
\hline
\end{tabular}

Kaynak: Wampler, s.56.

Tablo 4'e göre katılımcı bütçe sürecinde önceliklendirme ziyaretleri ile proje yerlerinin gezilmesi projelerin onaylanmasında yol gösterici olmaktadır. Buradaki önceliklendirme ziyaretleri, proje öncesi fizibilite çalışması şeklindedir. Söz konusu belirlenen projelerin yürütülmesi birkaç yılı almaktadır. Bu açıdan aralıklı sürelerle gerçekleştirilen "gözden geçirme toplantıları" yapılabilmektedir (Ergen, 2012: 328). Katılımcı bütçenin bu sürecinde en önemli olgu projeleri ayakta tutacak mali kaynaklardır. Bu anlamda katılımc bütçe süreci aslında proje değerlendirme ve izleme açısından devam eden bir süreçtir. Bazı projeler zamana yaygın bir şekilde gerçekleştirilmektedir (Anwar Shah, 2007:aktaran; Wampler, 2007: 24).

\subsection{Dünyada Seçilmiş Katılımcı Bütçe Modelleri}

Bu bölümde, katılımcı bütçe dünya uygulamaları içinde Kuzey Amerika eyaleti Newyork ve Güney Asya'da bulunan Hindistan'ın Maharaştra eyaletinde yer alan Pune şehrinde uygulanan katılımcı bütçe uygulaması örneği bu bölümde incelenmektedir.

\subsubsection{Amerika Birleşik Devletleri New York Eyaleti}

New York' ta katılımcı bütçe uygulaması topluluk üyelerinin, gönüllülerin, sivil toplum ve benzer gençlik örgütlerinin bir araya gelmesiyle şekillenmektedir. New York' ta vatandaşlar kamu bütçesinin bir kısmını nasıl harcayacaklarına karar vermektedirler. New York, katılımcı bütçe pilot uygulamasını 2011 yılında gerçekleştirilmiştir. Pilot uygulama, 51 üyenin çoğunluğu ile oluşturulan 31 konsey üyesinin katılımı ile gerçekleştirilmiştir. Konsey üyelerinin katılımcı bütçe projelerini oylaması katılımcı bütçeleme sürecini başlatmaktadır. Konsey üyeleri, halkın aktif katııımını sağlamak adına vatandaşları oylamaya davet etmektedir. Bunu kamu spotları, afişler, pankartlar, 
sosyal medya ve sokak stantları kurarak gerçekleştirmektedir. Halk katılımı ile oylama aşamasına gelen projelerde kent öncelikleri önem arz etmektedir (Kasdan \& Markman, 2017:1-3).

New York' ta gönüllülük çalışmaları ile vatandaşlar, katılımcı bütçe sürecinde yer almaktadırlar. Katılımcı bütçe faaliyetleri bir yıl sürmektedir. Konsey üyeleri, tüm topluluğun karar alma sürecine katılmaları için bütçesinden en az 1 milyon dolar alan Katılımcı Bütçeleme New York City' ye (Participatory Budgeting New York City) katılmayı seçmektedir. İnsanlar, bilinçli kararlar alabilmek adına bir yıl boyunca halka açık toplantılar planlamaktadırlar. Burada topluluk üyeleri yerel intiyaçları tartışmakta ve bu ihtiyaçları karşılamak için teklifler geliştirmektedir. Halk, teklifleri oylayarak hangi önerilerin fonlanacağına karar vermektedir. Katılımcı bütçe için ayrılan fonlar bitene kadar hangi projeler oylandıysa fon onlara tahsis edilmektedir. Süreci yönlendirmeye yardımcı olan şehir genelinde katılımcı bütçeyi destekleyen bireyler, topluluk organizasyonları ve Konsey üyelerinden oluşan bir (PBNYC) Katılımcı Bütçe Yönlendirme Komitesi bulunmaktadır. Yönlendirme komitesi, belirlemiş oldukları kural kitapçığına göre hareket etmektedir (http://council.nyc.gov/pb/cycle-5-results/, 2017). $\mathrm{Bu}$ kural kitapçığı ile yönlendirilen katılımcı bütçe kuralları temel olarak şunları hedeflemektedir (www.participatorybudgeting.org, 2017); hükümet politikalarını vatandaşlarla paylaşmak, sivil toplum katılımını artırmak, yeni grup liderleri geliştirmek, topluluk oluşturmak örgütlenmek, kamu harcamalarında eşitliği gözetmek yani en çok ihtiyaç duyulan yerlere kamu harcamalarını kanalize edip dengeyi sağlamak olarak sayılmaktadır. 2015-2016 arasında New York' ta projelerin oylama ayrıntılarına bakıldığında bu projelerin hangi illerde ve ne kadar tutarda olduğu şekil 6'da ifade edilmiştir.

Şekil 6. 2015-2016 Katılımcı Bütçe Dönemi New York 28 Belediye Bölgesinde î Başına Proje Harcamaları

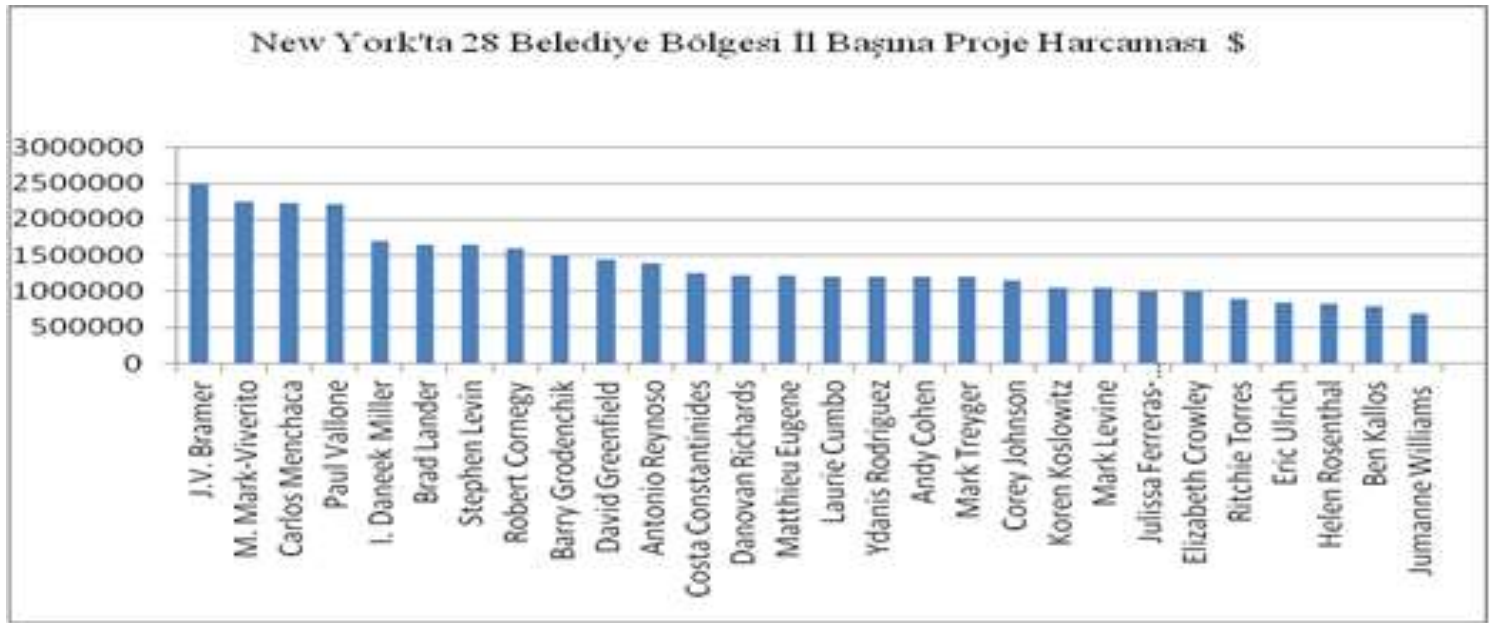

Kaynak: Participatory Budgeting, New York Council City, http://council.nyc.gov/pb/cycle-5-results/ (13.04.2017). 
Şekil 6'da görüldüğü üzere 2015-2016 yıllarında New York şehri sakinleri ilçelerinde önerilen beş favori projeyi seçmek için oy kullanmışlardır. 67.000 katılımcı, 28 belediye bölgesi için proje oylamıştır. Bu 28 belediye bölgesi şekilde görüldüğü üzere kendilerine tekabül eden maliyet toplamda 38 milyon dolardır. Newyork' ta yerel sermaye belli başlı kamu harcamalarına dağıtılmıştır. Bu harcamalar için oylar belli oranlarda dağılım göstermiştir. Şekil 7'de oyların dağııımına baktığımızda yapılacak kamu harcamalarının ilgili birimlere dağılımı şöyledir; eğitim için \%52, park ve rekreasyonun içim \%19, sanat ve kültür etkinlikleri için \%9, ulaşım için \%9, konut için $\% 7$, kamu güvenliği için \%3, huzur evi için \%1 olarak gerçekleşmiştir. Genel anlamda dikkat çeken husus, projeler için oyların \%52'si eğitim harcamaları için gerçekleşirken diğer projeler ise \%50'nin altında oranda çeşitlenmeler göstermiştir. 0 halde eğitime ayrılan harcama yüzdesi diğer birimlere nazaran $\% 52$ 'lik bir oranla daha fazla bir paya sahiptir.

\section{Şekil 7.2015-2016 Katılımcı Bütçe Dönemi New York 28 Belediye Bölgesinde Oylama Sonuçlarına Göre Fon Dağılımı}

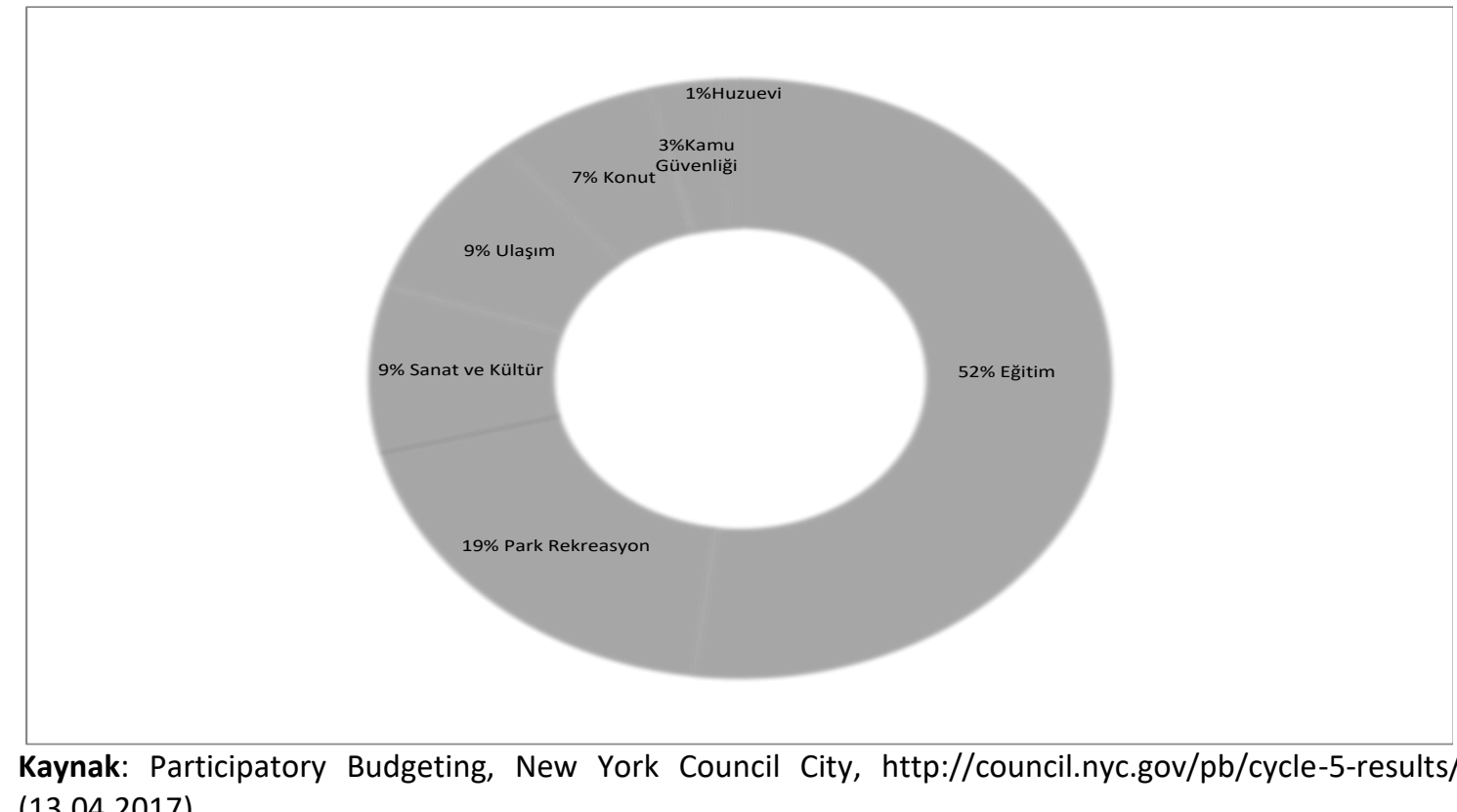
(13.04.2017).

Kazanan proje örneklerinden belli başlıcaları, Bölge 3 için Mühlenberg kütüphanesine serinletici sistem, Cnoll okulu için yeni bir kütüphane, Bölge 5 için çatı katı sera uygulaması, okul için bilgisayar alımıdır(Johnson, 2017).

Katılımcı bütçenin New York'ta geliştirilmesi ve daha iyi bir konuma gelmesi için hedefler belirlenmiştir. Bu hedefler (Kasdan \& Markman, 2017: 6); katılımcı bütçe swot analizleri gerçekleştirmek, katılımcıların farklılığını gözetmek, sivil varlığı genişletmek, kamu harcamalarının ne kadar adil olduğunu değerlendirmek, sosyal yardım çabalarını 
incelemek ve buna dair en iyi uygulamaları oluşturmak, halkı eğitmek olarak ifade edilmiştir.

Sonuç olarak, katılımcı bütçe konusunda New York'ta yapılan çalışmalar şunu göstermiştir; katılımcı bütçe süreci büyüdükçe ve kurumsallaştıkça yeni zorluklar ortaya çıkmaktadır. Katılımcı bütçe, göçmenler, gençler ve önceden tutsak edilmiş kişiler ve sivil mücadeleden dışlananları ilgilendirmeye devam etmektedir. Dikkat çeken husus şudur ki katılımcı bütçe seçmenlerinin \%16'sı ABD vatandaşı olmadığı için oy veremeyeceğini açıklamıştır. Bu yüzden son zamanlarda göçmen toplulukların katılımının arttırılması için dil meselesinin çözümü üzerinde durulmakta ve katılımım arttırma hedeflenmektedir (Kasdan \& Markman, 2017: 14).

\subsubsection{Hindistan-Pune}

Hindistan' da katılımcı bütçe süreci Sosyal ve Beşeri Kalkınma Girişimi (DISHA) olan yerel gönüllü organizasyon ile gerçekleştirilmeye çalışılmıştır. DISHA olarak adlandırılan bu organizasyon (Development Initiative For Social and Human Action) 1985 'te kurulmuş olup yaşam koşullarını iyileştirmeyi amaçlamaktadır. Eğitim ve sağlık alanında çalışmalara yoğunluk veren DISHA, özellikle katılımcı bütçe konusunda bilgilendirme ve eğitimler gerçekleştirmektedir. Bu anlamda sivil toplum örgütleri, devletin yasama meclisi üyeleri siyasi partiler üst düzey kamu yöneticileri DISHA' nın bulgularını ve çalışmalarını önemsemiştir(Fölscher, 2007: 167).

Pune' de katılımcı bütçe daha çok mahalle gecekondu iyileştirmeleri, eğitim ve sağlık alanında olmuştur. Yerel yönetimin mahalle ve gecekondu iyileştirmeleri konusunda toplanan gönüllü vatandaşlar Topluluk Geliştirme organizasyonunun desteği ile mahalle komiteleri oluşturmuştur. Katılımcı sivil kesim 2005 yılında Pune Belediye Teşkilatı (PMC-Pune Municipal Council-) ile toplantı düzenleyip katılımcı bütçenin temellerini atmıştır (http://www.nfi.org.in/our-programs/localgovernance/budget-work-india, 2017).

Hindistan'da 2006 yılında katılımcı bütçeyi ilk kez uygulayan şehir Hindistan'ın dokuzuncu büyük kenti olan Pune'dir. Pune, 3.2 milyonluk nüfusa sahip ve farklı ekonomik statülerden insanlara ev sahipliği yapmaktadır. Pune' de vatandaşların bazısı son derece fakir ve gecekonduda yaşarken bazıları da son derece zengindir. Vatandaşlar, bütçe prosedürünün farkında olmaksızın hayatlarına devam etmektedirler. Katılım ise yerel seçimlere katılmakla ifade edilmektedir. Pune' de katılımcı bütçeleme, bütçe oluşturma ve yürütme sürecini daha kapsayıcı, şeffaf, hesap verebilir ve etkili kılmak için doğrudan bütçelendirmeye doğrudan vatandaş katılımı için bir forum oluşturmayı amaçlamaktadır. Pune' de katılımcı bütçe süreci 6 adımdan oluşmaktadır (http://www.nfi.org.in/our-programs/local-governance/budget-workindia, 2017);

1. Pune Belediye Teşkilatı ofisinde Hazırlık Toplantısı yapılmaktadır ve bu toplantıya genelde PMC Başkanı, Yurttaş Kolaylaştırma Merkezi, Belediye Komiseri ve 
Janwani' nin başkanı ve Çevre Eğitim Merkezi katılmaktadır. Bu toplantı, Pune' de her yıl katılımcı bütçenin başladığını ifade etmektedir. Bu toplantıda, katılımcı bütçeye ilişkin çeşitli kararlar, tanıtım ve bütçe yaratma için diğer ek fikirler tartışılmaktadır.

2. Katılımcı bütçenin tanıtımı yapılmaktadır. Pune' deki katılımcı bütçe, herkese açık olmasına rağmen vatandaşlar katılım sağlamadıkları için katılımcı bütçenin tanıtımı en önemli adımdır. Tanıtıma yönelik ilk adım, yerel gazetelerde vatandaşlara öneriler sunan resmi bir reklamdır. Bu reklamlar, PMC ofisine önerilerin açılış ve kapanış tarihleriyle ilgili bilgiler vermektedir. Bunun dışında PMC ayrıca vatandaşlara telefonla bilgilendirme araması da yapabilmektedir.

3. Öneri formlarının gönderilmesi, vatandaşların çevrimiçi bütçe öneri formlarını doldurması istenmektedir. Doldurulan formların PMC bürosuna gönderilmesi istenmektedir. Konular; kenti yolları, sokak lambaları, trafik sinyalleri, otobüs durakları, halka açık otoparklar, kamu tuvaletleri, katı atık yönetimi, su temini, yağmursuyu, bahçeler, kamu binaları ve diğerler konuları kapsamaktadır.

4. Sınıflandırma, derleme ve işin maliyeti, tüm bütçe öneri formlarında yer alan her öneri yanına tarih not edilerek belli kodlar ile ortalama maliyetleri kaydedilmektedir.

5. Nihai belediye bütçesinin oluşturulması, 14 merkezdeki tüm idari bölgede önceliklendirme toplantısından sonra gerçekleşmektedir. Bu açıdan Pune Belediye Teşkilatına 2 milyon tutarında bütçe temin edilmiştir. PMC, katılımcı bütçeye dair gerçekleştirdiği tüm değerlendirmeler neticesinde nihai bütçeyi ilan ederek katılımcı bütçe sürecini sonlandırmaktadır.

Pune' deki katılımcı bütçe uygulamasının sonuçları değerlendirildiğinde olumluolumsuz yönler görülmektedir. Pune' de son 7 yıldır başarılı bir şekilde gerçekleştirilen katılımcı bütçe örneği, vatandaşların katılımına yönelik siyasi iradenin demokratik anlamda geliştiğini göstermektedir. Vatandaşlar, karar alma hakları konusunda daha aktif olmuş, farkındalıklarını ve katılımlarını arttırmışlardır. Pune, 2012-2013'de vatandaşlardan gelen yalnızca 600 öneriye tanık olurken, sayı 2013-2014'te 3.300'e, 2014-2015 yılları arasında 6.000'e öneriye yükselmiştir. Üçüncüsü, Pune' de 2010 yazında yapılan bir anket çalışmasında projeler içinde \% 18.18 tamamlanmamış projeler yer alırken projelerin \% 14' ünün yapılmadığı ifade edilmiştir. Tüm projeler içinde tamamlanan projelerin oranı \%18 olarak gerçekleşmiştir. Pune' de katılımcı bütçenin olumsuz yönlerine bakacak olursak, katılımcı bütçenin temel amaçlarından birinin bütçe tahsis sürecinde kapsayıcılık ve şeffaflık gerçeği önemli bir iyileşme göstermediği ifade edilmiştir. Bütçe önceliklendirme fikri 2008 yılından bu yana askıya alınmıştır ve böylece bütçe tahsis prosedürüne vatandaşların katılımı sadece öneri formlarını göndererek kısıtlanmıştır. Bu suretle karar verme yetkisi siyasetçilerin ve hükümet yetkililerinin inisiyatifine bırakılmıştır. Bu anlamda sosyal adalete gerçekten ulaşılamadığı ifade edilmektedir. Pune' de yoksul kesimi herhangi bir resmi biçimde bir araya getirme yöntemi ve ihtiyaçlarına daha fazla dikkat etmek için herhangi bir özel 
politika mevcut değildir. Son olarak, önerilen bir gelişme olmamıştır. Yetkililer vatandaşlara, önerilerin kabul veya reddedilme temelini asla bildirmemektedirler. Böylece, karar vermede şeffaflık olmaması yüzünden vatandaşların hesap verebilirlik talep edebilecekleri herhangi bir kanalı olmadığı için hesap verme sorumluluğu da yoktur. Pune'de gecekondu bölgeleri için katılımcı bütçe kapsamında toplantılar düzenlenmiştir fakat gecekondu mahallinin çoğunun okur yazar olmaması sebebiyle süreç tam olarak yerleşmemiştir. Gönüllü vatandaşlar önerileri bütçelendirerek PMC' $^{\prime}$ ye rapor göndermiştir. Ancak, rapor reddedilmiş ve inisiyatif Pune'yi yöneten parti tarafından kabul edilmemiştir. Yerel yönetimin üyeleri demokrasi ruhunu korumak için vatandaşların katılımının önemini fark etmediği için bu durumu 'Demokrasi Ölümü' olarak nitelendirmiştir (Menon \& Amarnath, 2013: 10).

Harcamalara bakıldığında daha çok altı ana alanda yoğunlaşmıştır. Bunlar, yol, elektrik, binalar, arızalanma, su arzı ve drenaja yönelik olarak gerçekleşmiştir. Bu sayılanlar arasında yol kalkınması maliyetlendirme bakımından en fazla payı alan sektör olmuştur (Keruwala \& Maya Roy, 2017).

Pune ve Porto Alegre katılımcı bütçe uygulaması kıyaslandığında şöyle bir durum ortaya çıkmaktadır; Porto Alegre' de vatandaşlar sesini düzenli tartışmalı forumlar vasıtasıyla sunmuşlardır, aynı zamanda önemli politika kararı için oy kullanıp, bütçeyi gözden geçirmişlerdir. Porto Alegre'de katılımcı vatandaşlar bütçelerinin bölge için önceliğini belirlemede yer alıp ve seslerini temsil etmekle resmen sorumlu olan temsilcileri seçmişlerdir. Pune' de ise katılımcı bütçe süreci sadece danışmanlıktan doğrudan katılıma dönüştürmek amacıyla burada katılımcı bütçe sürecinin tekrar gözden geçirilmesi gereği uzmanlarca ifade edilmiştir (https://www.participedia.net/ en/cases/pune-participatory-budgeting, 2017).

\section{Manisa Büyükşehir Belediyesi Merkez İlçeler Meclis Üyelerinin Manisa'da Katılımcı Bütçe Uygulamasına Yönelik Görüş ve Tutumlarına Dair Bir Araştırma}

Manisa merkez ilçeleri Manisa Yunusemre ilç̧e Belediyesi ve Manisa Şehzadeler Illçe Belediyesi'nde katılımcı bütçe uygulamalarının ne ölçüde gerçekleştirildiği konusu nitel araştırmanın temelini oluşturmaktadır. Manisa Büyükşehir Belediye Meclisi bünyesinde üye sayısı toplamda seksen sekiz kişidir. Görüşme yöntemi için belirlenen ana kütle Manisa Büyükşehir Belediyesi merkez ilçeler meclis üyeleridir. Manisa Büyükşehir Belediyesi Merkez Illçeler Meclis Üyeleri ise Manisa Büyükşehir Belediye başkanı Cengiz Ergün de dâhil olmak üzere on beş kişiden oluşmaktadır. Görüşme yöntemi kapsamında nitel araştırmada yer alan gönüllü katılımcı sayısı on beştir. Söz konusu on beş kişiden oluşan ana kütleye on üç gönüllü katılımcı meclis üyesine ek olarak Manisa Büyükşehir Belediyesi Kent Konseyi başkanı ve bir bürokrat da katılım sağlamıştır. Bu anlamda görüşme araştırmasında on beş katılımcıdan elde edilen tüm bulgular tüm katılımcıların vermiş oldukları bilgiler kapsamında çalışmaya aktarılmıştır. 


\subsection{Araştırma Yöntemi ve Katılımcıların Araştırmaya Katılımı}

Nitel araştırma yöntemlerinden görüşme yöntemi içinde yer alan yarı yapılandırılmış görüşme yönteminde araştırmacı genel bir yol haritasına sahiptir. Gönüllü katılımcının vereceği bilgiler dahilinde araştırmacı var olan bir durumu ortaya çıkarmaya çalışmaktadır. Yarı yapılandırılmış görüşme tekniğini doğası itibari ile temel çalışmaya açıklayıcı bir yaklaşım katmaktadır. Araştırmacı bu noktada sorular sorarken detaylara girebilme fırsatı yakalayabilmektedir. Böylece tek düze bir çalışmadan kaçınılmaktadır. Bununla birlikte soruların sırası konunun akışını takip eder biçimde ilerlemektedir. Aksi halde araştırma karışık bir yol izleyebilir. Bunun önüne geçebilmek için görüşme sorularının konunun içeriğine girecek şekilde devam etmesi arzu edilen bir durumdur. Bu çalışmada yarı yapılandırılmış görüşme yöntemi kullanılmıştır ve elde edilen bilgiler katılımcıların da onayı ile çalışmaya aktarılmıştır( Saunders, Lewis \& Thornhill, 2017).

Gönüllü katılımcılara yöneltilen görüşme soruları form belgesi içinde katılımcılara temin edilmiştir. Katılımcılar görüşme sorularını cevaplarken form belgesini de görmüşlerdir. Araştırma sonunda elde edilen bilgiler Celal Bayar Üniversitesi Etik İzin Onayı ile çalışmaya aktarıımıştır.

\subsubsection{Katılımcıların Demografik Özellikleri}

Araştırma kapsamında yer alan gönüllü katılımcılar, Manisa Büyükşehir Belediyesi Merkez ilıçeler gönüllü katılımcı meclis üyelerinin cinsiyet, yaş aralığı, medeni durumu, öğrenim durumu, sivil toplum kuruluşuna üyelik durumu konusunda bilgi edinmeye yönelik beş başlıkta kendilerine yöneltilen soruları içermektedir. Bu anlamda, tablo 5 'te ifade edildiği üzere her bir gönüllü katılımcının demografik bilgileri incelenmektedir.

Tablo 5. Manisa Büyükşehir Belediyesi Merkez ilçeler Gönüllü Katılımcılar

\begin{tabular}{|c|c|c|c|c|c|c|}
\hline Katılımcı & Cinsiyet & Yaş Aralığı & $\begin{array}{c}\text { Medeni } \\
\text { Durum }\end{array}$ & $\begin{array}{c}\text { Öğrenim } \\
\text { Durumu }\end{array}$ & $\begin{array}{c}\text { STK' ya Üyelik } \\
\text { Durumu }\end{array}$ & Meslek \\
\hline K1 & Erkek & $41-50$ & Evli & Lise & Birden Fazla & Esnaf \\
\hline K2 & Erkek & $31-40$ & Evli & Lisans & Birden Fazla & Mimar \\
\hline K3 & Erkek & $41-50$ & Evli & Lisans & Birden Fazla & Mimar \\
\hline K4 & Kadın & $41-50$ & Evli & Ön Lisans & Birden Fazla & Memur \\
\hline K5 & Erkek & $41-50$ & Evli & Lisans & Birden Fazla & Esnaf \\
\hline K6 & Erkek & $51-60$ & Evli & Doktora & Birden Fazla & Memur \\
\hline K7 & Erkek & $41-50$ & Evli & Lise & Birden Fazla & Memur \\
\hline K8 & Erkek & $\begin{array}{c}61 \text { yaş ve } \\
\text { üzeri }\end{array}$ & Evli & Lisans & Birden Fazla & Memur \\
\hline K9 & Erkek & $51-60$ & Evli & Lisans & Birden Fazla & Doktor \\
\hline K10 & Erkek & $41-50$ & Evli & $\begin{array}{c}\text { Yüksek } \\
\text { Lisans }\end{array}$ & Birden Fazla & Mühendis \\
\hline
\end{tabular}


Doğan, G. \& Çetin Gerger, G. (2018). “Manisa Büyükşehir Belediyesi Meclis Üyelerinin Katılımcı Bütçe Uygulamasına Yönelik Görüşleri”, International Journal of Public Finance, Vol.3, No.2, pp. 205-231.

\begin{tabular}{|c|c|c|c|c|c|c|}
\hline K11 & Erkek & $51-60$ & Evli & Lisans & Birden Fazla & Mali Müşavir \\
\hline K12 & Erkek & $51-60$ & Evli & Lisans & Birden Fazla & Memur \\
\hline K13 & Erkek & $51-60$ & Evli & Lisans & Birden Fazla & Memur \\
\hline K14 & Erkek & $51-60$ & Evli & Ön Lisans & Birden Fazla & Memur \\
\hline K15 & Erkek & $31-40$ & Evli & $\begin{array}{c}\text { Yüksek } \\
\text { Lisans }\end{array}$ & Birden Fazla & Memur \\
\hline
\end{tabular}

Tablo 5'e incelendiğinde katılımcılardan edinilen demografik bilgilerin ayrıntılarını görmekteyiz. Katılımcıların genel demografik yapısına bakıldığında on dört katılımcıdan birinin kadın diğer on üç katılımcının erkek olduğu, yaş aralıklarının ve öğrenim durumlarının çeşitlilik gösterdiği, hepsinin evli ve birden fazla sivil toplum kuruluşuna üye olduğu görülmektedir.

Katılımcı 1'den katılımcı 13 de dahil olmak üzere tüm katılımcılar, Manisa Büyükşehir Belediyesi Merkez İlçeler Belediye Meclis üyelerinin gönüllü katılımcılarından oluşmaktadır. Diğer katılımcılar, Manisa Kent Konseyi başkanı ve bürokrasiden gelen gönüllü katılımcıdır.

\subsection{Verilere Ulaşma Süresi}

Yapılan nitel araştırmada katılımcılar, belirlenen tarihlerde belirlenen süreler içinde sorulara yanıt vermişlerdir. Özet şeklinde sunulan tablo aşağıda ifade edilmiştir.

Tablo 6. Manisa Büyükşehir Belediyesi Merkez ilcçeler Meclis Üyeleri Gönüllü Katılımcılarla Gerçekleştirilen Görüşme Süreleri ve Tarihleri

\begin{tabular}{|c|l|c|c|}
\hline Katılımcılar & \multicolumn{1}{|c|}{ Görüşme Tarihi } & Görüşme Saati & Görüşme Süresi \\
\hline K1 & 16 Ağustos 2017 & $16: 46$ & $00: 49: 33$ \\
\hline K2 & 17 Ağustos 2017 & $11: 00$ & $00: 52: 04$ \\
\hline K3 & 17 Ağustos 2017 & $12: 20$ & $00: 28: 16$ \\
\hline K4 & 17 Ağustos 2017 & $13: 40$ & $00: 54: 53$ \\
\hline K5 & 17 Ağustos 2017 & 17.00 & $00: 30: 00$ \\
\hline K6 & 18 Ağustos 2017 & $11: 46$ & $00: 59: 41$ \\
\hline K7 & 18 Ağustos 2017 & $15: 05$ & $00: 40: 00$ \\
\hline K8 & 7 Kasım 2017 & $10: 30$ & $01: 00: 00$ \\
\hline K9 & 13 Eylül 2017 & $19: 00$ & $00: 58: 23$ \\
\hline K10 & 14 Eylül 2017 & $19: 05$ & $01: 03: 16$ \\
\hline K11 & 14 Eylül 2017 & $20: 30$ & $00: 55: 04$ \\
\hline K12 & 7 Kasım 2017 & $19: 00$ & $00: 00: 05$ \\
\hline K13 & 21 Aralık 2017 & $11: 00$ & $00: 30: 00$ \\
\hline K14 & 24 Ağustos 2017 & $10: 30$ & $00: 46: 58$ \\
\hline K15 & 18 Ağustos 2017 & $9: 30$ & $00: 30: 00$ \\
\hline & & & $10: 13: 21$ \\
\hline $\begin{array}{l}\text { Toplam Görüşme } \\
\text { Süresi }\end{array}$ & & & \\
\hline
\end{tabular}


Tablo 6'ya bakıldığında katılımcılarla gerçekleştirilen görüşmelerin tarihleri, görüşme saat dilimleri ve görüşme süreleri ifade edilmiştir. Randevu yöntemiyle görüşmeler önceden belirlenen bir takvim içerisinde gerçekleştirilmiştir. On beş katılımcının görüşlerinin alındığı çalışmada gerek aynı gün içinde gerekse farklı günlerde görüşmeler gerçekleştirilmiştir. Her katılımcı ile geçen görüşme süreleri katılımcıların müsait oldukları zaman içinde sınırlandırılmıştır. İki katılımcı mail üzerinden sorulara genel ve özet cevap göndermiştir. Manisa Büyükşehir Belediyesi Merkez İlçeler Meclis Üyelerinden gönüllü katılımcıların ikisi haricinde diğerleri yüz yüze görüşme talebini kabul etmiştir. Tüm katılımcılarla gerçekleştirilen görüşme süresi toplamda on saat, on üç dakika ve yirmi bir saniyedir.

\subsection{Araştırma Verilerinin Toplanması}

Yarı yapılandırılmış görüşme tekniği kullanılarak gerçekleştirilen araştırmada verilen cevapları sağlıklı bir şekilde çalışmaya aktarabilmek adına ses kayıt cihazı ve not alma yöntemi kullanılmıştır. Bu yöntemler sayesinde gönüllü katılımcıların tarafımıza sağlamış oldukları bilgiler objektif bir şekilde çalışmada derlenmiştir (Esen Altunay, Gülşin Oral \& Münevver Yalçınkaya, 2014: 66).

\subsubsection{Verilerin Güvenilirliği}

Araştırmanın güvenilir olması ve ilerleyen zamanlarda diğer çalışmalara yol göstermesi adına gönüllü katılımcılara yöneltilen soruların yanıtları yorum yapılmaksızın çalışmaya aktarılmıştır. Güvenilirliğin hem katılımcılar hem de araştırmacı adına güçlü olması için elde edilen bilgiler arşivleme yöntemi ile saklanmaktadır (Altunay, Oral \& Yalçınkaya, 2014: 66).

Bununla birlikte gönüllü katılımcıların isimleri, görüşleri gizlilik esasına göre kodlanarak "Katılımcı K1,K2,K3...." şeklinde ifade edilmiştir. Bu anlamda ilgili konu başlıkları altında katılımcıların görüş ve önerileri tarafsız olarak özet halinde tablo şeklinde sunulmuştur (Altunay \& Oral, 2014: 69).

\subsubsection{Verilerin Analizi}

Yapılan araştırma yöntemlerinden görüşme verilerinin analizi ilgili başlıklarda sunulmaktadır.

\subsubsection{Görüşme Verilerinin Analizi}

Araştırma verilerinin çalışmaya aktarılmasında betimsel analiz yöntemi uygulanmıştır. Bu yöntem, katılımcıların söz ve düşüncelerinin doğrudan alıntılama yöntemiyle çalışmaya aktarılmasını ifade etmektedir. Katılımcıların görüşleri çalışma 
bulgularının yer aldığı bölümde özellikle tırnak içinde alıntılarla ifade edilmektedir. Çalışmanın özet şeklinde ifade edilmesi için benzer yanıtlar tablolaştırılmıştır. Katılımcılar tarafından verilen örnek olaylar çalışmanın değerlendirilmesinde yol gösterici olmaktadır (Gülsen Ünver, Nilay T. Bümen \& Makbule Başbay, 2010: 66).

\section{Görüşme Sonucu Elde Edilen Bulgular}

Bu bölümde Manisa Büyükşehir Belediyesi Merkez İlçe Belediyeleri Meclis Üyelerinin gönüllü katılımı ile edinilen bilgi, deneyim, görüş ve öneriler çeşitli başlıklar altında ifade edilmektedir. Manisa Yunusemre ve Şehzadeler Merkez İlçelerinde kamu harcamaların gerçekleştirilmesinde ve bütçe sürecinde halkın bu harcamalarda ne ölçüde fikir beyan ettiği örneklerle ifade edilmektedir. Manisa Merkez İlçe Meclis Üyelerinin katılımcılığa ve katılımcı bütçeye dair görüş, fikir ve önerilerini çalışmada yer almaktadır. Katılımcıların ilgili sınıflandırmada yer alan sorulara yanıt verip vermemesi hususu özgür iradelerine bırakılmıştır.

\subsection{Bireysel Bulgular ve Tutumlar}

Katılımcılarla bireysel olarak yapılan görüşmelerde gönüllülük esasıyla cevaplandırılan sorular olduğu gibi net olarak cevap alınamayan sorular da olmuştur. Her bir katılımcı görüşme süresi içinde görüşme sorularını kendi bilgisi ve tecrübesi dahilinde cevaplamaya çalışmıştır. Bu anlamda Manisa Büyükşehir Belediyesi Merkez İlçeler Meclis Üyelerinin vatandaş katılımına, katılımcı bütçeye ve Manisa'da uygulanması düşünülebilecek bir katılımcı bütçe sürecine dair görüş ve öneriler çalışmada mevcuttur. Katılımcı bütçenin kavramını duyup duymadıklarına dair yanıtlar tablo 7'de ifade edilmektedir.

Tablo 7. Katılımcı Bütçe Kavramı

\begin{tabular}{|c|l|}
\hline Katılımcılar & “Katılımcı Bütçe Kavramını Duydunuz mu?” \\
\hline K1 & Duymadım, açıklama beklemekteyim. \\
\hline K2 & Duymadım, açıklama beklemekteyim. \\
\hline K3 & Duydum ama ayrıntılı olarak bilmiyorum. \\
\hline K4 & Duydum ama ayrıntılı olarak bilmiyorum. \\
\hline K5 & Duydum. \\
\hline K6 & Duymadım, açıklama beklemekteyim \\
\hline K7 & Duymadım, açıklama beklemekteyim \\
\hline K8 & Duydum ama ayrıntılı olarak bilmiyorum. \\
\hline K9 & Duydum. \\
\hline K10 & Duymadım, açıklama beklemekteyim \\
\hline
\end{tabular}


Doğan, G. \& Çetin Gerger, G. (2018). “Manisa Büyükşehir Belediyesi Meclis Üyelerinin Katılımcı Bütçe

Uygulamasına Yönelik Görüşleri”, International Journal of Public Finance, Vol.3, No.2, pp. 205-231.

\begin{tabular}{|l|l|}
\hline K11 & Duydum ama ayrıntılı olarak bilmiyorum. \\
\hline K12 & - \\
\hline K13 & Duydum, yeterince bilgi sahibiyim. \\
\hline K14 & Duydum ama ayrıntılı olarak bilmiyorum \\
\hline K15 & Duydum ama ayrıntılı olarak bilmiyorum \\
\hline
\end{tabular}

Tablo 7'de özetlendiği üzere katılımcıların çoğu katılımcı bütçe hakkında genel ya da detaylı bilgi sahibi değildir. Kendilerine katılımcı bütçe konusunda kısa bir açıklama yapıldıktan sonra diğer soruları yanıtlamaya çalışmışlardır.

Katılımcılara yöneltilen diğer soru ise Manisa merkez ilçelerde vatandaş katılımının hangi yöntemlerle gerçekleştiği konusudur. Katılımcıların ifadeleri tablo 8 'de özetlendiği gibidir.

Tablo 8. Manisa Merkez IIlçeler Vatandaş Katılım Yöntemleri

\begin{tabular}{|c|l|}
\hline Katılımcılar & \multicolumn{1}{|c|}{ “Manisa'da Vatandaş Katılımı ve Yöntemleri nelerdir?” } \\
\hline K1 & Toplumsal bir bakış açısı yok, vatandaş harekete geçmiyor. \\
\hline K2 & Güçlü bir halk katııımı mevcut değil. \\
\hline K3 & Vatandaşa yöneltilen anketler. \\
\hline K4 & $\begin{array}{l}\text { Hizmet öncesi hizmet sonrası anketler, sosyal doku ekibi, çağrı } \\
\text { merkezi, beyaz masa }\end{array}$ \\
\hline K5 & Yerel temsilciler vasıtasıyla \\
\hline K6 & Mahalle muhtarları, STK temsilcileri, kent konseyi \\
\hline K7 & Beyaz masa, sosyal doku ekibi, çağrı merkezi \\
\hline K8 & Muhtarlar, kent konseyi, meclis üyelerine dilekçe \\
\hline K9 & Belediye başkanının halkı dinlemesi \\
\hline K10 & STK' lardan meclis komisyonlarına ulaşmak yolu ile \\
\hline K11 & $\begin{array}{l}\text { Ciddi bir halk katılımı ve talebi mevcut değil. Muhtarlar ve kurullar } \\
\text { aracılığı ile... }\end{array}$ \\
\hline K12 & - \\
\hline K13 & Kamu kurum ve kuruluşları, STK'lar, odalar ve dernekler... \\
\hline K14 & Vatandaş katılımı aktif olarak gerçekleşmemektedir. \\
\hline K15 & Kent konseyi bünyesindeki meclislerle katılım gerçekleşmektedir. \\
\hline
\end{tabular}

Tablo 8'de ifade edildiği üzere öncelikli vurgulanan hususun Manisa merkez ilçelerde kamu projeleri ve diğer talepler noktasında vatandaş katılımının ve vatandaş duyarlılığının mevcut olmadığıdır. Kente dair çalışmalar yürütecek kişi ya da kişilerin gerek bireysel gerekse bağlı olduğu sivil toplum kuruluşu ile katılımı muhtarlar, dilekçeler, beyaz masa, çağrı merkezi vb. şeklindedir. Bir diğer husus ise; Manisa 
Doğan, G. \& Çetin Gerger, G. (2018). “Manisa Büyükşehir Belediyesi Meclis Üyelerinin Katılımcı Bütçe

Uygulamasına Yönelik Görüşleri”, International Journal of Public Finance, Vol.3, No.2, pp. 205-231.

Büyükşehir Belediyesi Kent Konseyi'nde katılımcı bütçeye dair neler gerçekleştirildiğidir. Bu açıdan Tablo 9 aşağıda sunulmuştur.

Tablo 9. Manisa Büyükşehir Belediyesi Kent Konseyi

\begin{tabular}{|c|l|}
\hline $\begin{array}{c}\text { Manisa Kent Konseyi } \\
\text { Hakkında Bilgi ve Deneyim } \\
\text { Sahibi Olan Katılımcılar }\end{array}$ & \multicolumn{1}{|c|}{$\begin{array}{c}\text { Manisa Büyükşehir Belediyesi Kent Konseyi ve } \\
\text { Katılım }\end{array}$} \\
\hline K1 & Katılım konusunda kent konseyi uygun olabilir. \\
\hline K6 & $\begin{array}{l}\text { Kent konseyinde yer alan 4 meclis ne tür hizmetlerin } \\
\text { gerekli olduğunu vatandaş talepleri doğrultusunda } \\
\text { raporlaştırmaktadır. }\end{array}$ \\
\hline K8 & $\begin{array}{l}\text { Kent Konseyi sayesinde vatandaş katılımı ile hayata } \\
\text { geçirilen bazı uygulamalar olmuştur. }\end{array}$ \\
\hline K13 & $\begin{array}{l}\text { Kent konseyinde rapor haline getirilen talepler } \\
\text { belediye meclisimize ulaşmakta ve değerlendirmeye } \\
\text { alınmaktadır. }\end{array}$ \\
\hline K14 & $\begin{array}{l}\text { Resmi olarak adı geçen bir katılımcı bütçe platformu } \\
\text { yoktur. }\end{array}$ \\
\hline
\end{tabular}

Tablo 9 incelendiğinde Manisa Kent Konseyi'nin katılımcı uygulamalar açısından uygun olduğu ifade edilmektedir. Manisa Büyükşehir Belediyesi Kent Konseyi'nde resmi anlamda herhangi bir katılımcı bütçe platformu olmadığı ifade edilmiştir. Manisa Kent Konseyi'nde gerçekleştirilen çalışmaların genelde kültürel faaliyetler olduğu ifade edilmektedir. Manisa merkez ilçelerde uygulanması düşünülecek bir katılımcı bütçe için kent konseyi bünyesinde aktif olan Kadın, Engelli ve Gençlik meclislerinin yanında "Katılımcı Bütçe Meclisi"nin açılması öngörülmüştür(K6). Katılımcıların genel kanaati katılımcı bütçe uygulamasının Manisa Büyükşehir Belediyesi Kent Konseyi birimiyle hayata geçirilmesi hususunda olmuştur. Nitekim Manisa merkezden hareket edip Muradiye semtinde yer alan Manisa Celal Bayar Üniversitesi Kampüs yerleşkesine hareket eden 21 numara halk otobüsünün öğrencilerin talebi doğrultusunda hayata geçirildiği örneği verilmiştir(K8).

Bir diğer husus ise Manisa merkez ilçelerde uygulanması düşünülecek katılımcı bütçenin olumlu ve olumsuz yönleridir. Katılımcılar bu sorunu örneklerle anlatmaya çalışmışlardır. Katılımcılar, Manisa'da hayata geçirilecek katılımcı bütçe uygulaması konusunda birtakım engeller olabileceğini örnek olaylarla ifade etmişlerdir. Katılımcıların vermiş oldukları bu örnek olaylar doğrudan tırnak içinde ifade edilmiştir. Bu engellerden birincisi siyaset olarak karşımıza çıkmaktadır.

"Katılımcı belediyecilik Manisa'da siyaset açmazına takılıyor. Belediye hizmetlerinin değerlendirilmesi konusunda vatandaşlarla gerçekleştirilen hizmet memnuniyeti anketleri karşısında halk hizmetten memnun olup olmama durumuna 
göre değil, tamamen destekledikleri siyasi parti unsuruna göre yanıt vermek durumunda olabiliyorlar."(K3).

"Manisa'da belediye hizmetlerinin değerlendirilmesi konusunda hizmet öncesi ve hizmet sonrası yapılan anketlerde vatandaşlar bu anketlerin siyaset adına yapıldığını düşünüp yanıt vermek istemeyebiliyorlar. Burada belediyecilik ile siyaset birbirine girebiliyor. Vatandaş kendi siyasi görüşünden olan partinin gerçekleştirdiği hizmetin kamu yararına uygun olup olamayacağı tartmadan tamamen siyasi parti odaklı yanıtlar verebilmektedir."(K4).

"Siyasi engeller sadece vatandaş ve belediye arasında kalmıyor, büyükşehir belediyesi ve merkez ilçe belediyeleri arasında da yaşanabiliyor. Farklı siyasi görüşlerin yer aldığı ilçe belediyeleri büyükşehirden pay alırken siyaset engeline takılabiliyor. Neticede kamu yararı gözetilerek gerçekleştirilen belediye projelerinde son söz Büyükşehir Belediye Başkanına aittir. Büyükşehir Belediye Başkanı ve diğer belediye başkanları seçimlerden önce seçim vaatleri vermektedir. Seçimlerden sonra altı ay içinde stratejik planlar yapılmak zorundadır. Stratejik planlar seçim vaatlerine göre oluşturulmaktadır. Beş yıl için oluşturulan stratejik planlar daha sonra yıllık bazda performans planlarına dönüştürülmektedir. Performans planı ise müdürlüklerin iş planıdır. Seçim vaatleri kamu hizmetine bu ve kamu görevlerine bu şekilde yansımaktadır. Vurgulamak istediğim nokta şudur ki, büyükşehir ve ilçe belediyeleri arasında siyasi açıdan farklı bir parti grubuna mensup olma durumu varsa kaynak aktarımı konusunda sıkıntılar yaşanabilmektedir. Bu noktada ilçe belediyelerinin halka büyükşehirden daha yakın oluşu neticesinde vatandaş katılımına da imkan veren kamu kurumlarıdır. Katılımcılık ile oluşturulmak istenen bir projede gerekli kaynağı bulamayan ilçe belediyesi bu anlamda siyaset engeli ile katılımcı belediyeciliği aktif kılamayacaktır. Üzerine çalışılan yeni oluşturulacak belediye kanununda büyükşehir belediyelerinin ilçe belediyelerine nüfus ve yüzölçümü kriterleri ile kaynak aktarımında yasal düzenlemelerin getirilmesi kamu yararına olacaktır. Böylece siyaset, katılımcılığa engel olmamalı, aksine gerekli düzenlemeler ile katılımcılığı desteklemelidir." (K15).

Siyaset engelinin üzerinde çokça duran katılımcılar diğer noktalar konusunda da birtakım görüşler sunmuşlardır.

Bir katılımcı, devlet bütçesi sürecinde vatandaş taleplerinin belli başlı projeler konusunda hayata geçirilmesi düşünülecek kamu harcamalarının bir sonraki yıl gerçekleşeceği hususunu katılımcı bütçenin olumsuz yönü olarak değerlendirmiştir.

Bir diğer katılımcı bütçe engelinin vatandaşlar olduğu ifade edilmiştir. Bazı katılımcılara göre bir muhitte bazı vatandaşlarca talep edilen kamu projesinin aynı muhit içinde farklı vatandaşlar tarafından kabul görmemesini örneklendirmişlerdir. 2014 yılı itibari ile büyükşehir olarak 17 ilçeye hizmet veren Manisa Büyükşehir Belediyesi'nin bu hizmet genişlemesi ile birlikte vatandaş taleplerine yetişebilmek konusunda zorluklar yaşandığı ifade edilmektedir. Katılımcılar bunun üzerine iki örnek olay ifade etmişlerdir. Birincisi, katı atıkları bertaraf etme tesisi projesinin vatandaşların tepkisi üzerine iptal edilmiş olmasıdır. 
"Manisa'nın Uzunburun mahallesinde katı atık bertaraf tesisleri açılacaktı. Bu tesisin çalışması Saruhanlı'nın Develi mahallesinde yapılması planlanıyordu. Öyle ki halk bu tesisin etrafa vereceği koku ve benzeri rahatsılıklarından dolayı istemedi. Yaklaşık seksen trilyonluk proje burada iptal edilmek durumunda kaldı. Şu sıralar Kula'nın Gökçeören ilçesine yapılması düşünülen projede amaç organik gübre elde edilmesi, katı atıkların dönüştürülmesi, atık suların damıtılıp tarımda sulamada kullanılmasıdır."(K11).

İkincisi ise kent düzeni ile ilgilidir. "Manisa Büyükşehir Belediyesinin özellikle kentin mimarisi konusunda gerçekleştireceği birtakım projeleri halka sorması durumunda olumsuzluklarla karşılaşacağı ortadadır. Bu bakımdan her konunun katılımcı bütçe ile oylanması ya da değerlendirilmesi durumunda ortada bir kaos oluşacaktır. İmar gibi ağır konularda vatandaş katılımı belediye yönetimini zor durumlarda bırakabilir. Manisa Ulucami ve çevresini düzenleme ve restore etme çalışmaları başlayacak. Ulucami' nin etrafındaki alanlar kamulaştırılacak ve oradaki halkı mağdur etmeden bir çözüm yolu bulunacak. Ulucami ve çevre düzenlemesi konusunda orada ikamet eden halka bu projenin gerçekleştirilip gerçekleştirilmemesi konusunu sormak istersek karşılaşacağımı cevap bellidir. Kimse evini ve oturduğu semti bırakıp başka bir yere gitmek istemeyecektir. Olursa da bu oran daha az bir orana tekabül edecektir. İşte burada her projenin halkla gerçekleştirilemeyeceği konusunu vurgulamak adına bu örneği vermek istedim. Tabii daha ufak çaplı projeler için değerlendirilebilir." (K8).

Katılımcı 3, katılımcı bütçe uygulamasında alternatif maliyetin olumsuz bir durum olacağını ifade etmiştir. Katılımcı bütçe çerçevesinde bir kamu harcaması gerçekleştirilirken bunun alternatif maliyetinin de planlaması gereğini ifade eden katılımcı şu örneği vermiştir; "Yunusemre ilçesine bağlı eskiden köy olarak adları geçen mahallelerden gelen düğün salonu talebi üzerine belediye ekibimiz harekete geçti. Bu mahallelerin şehir merkezindeki düğün salonlarına uzaklığı yaklaşık 18-20 km. 'dir. Bu anlamda gerekli görülen yerlere birkaç tane dügü̈n salonu yaptık. Bu kamu harcamasının üzerine biraz düşününce atıl bir harcama olabileceği saptanabilir. Köyde düğün yapılacağı zaman kullanılan dügün salonu yılda 2-3 kere olmaktadır. Bunun yanında o düğün salonlarının temizlenmesi ve düzenlenmesi için belediyeden bir ekip belli zaman aralıklarında ilgili salona gidip temizlik yapmaktadır. Bu da belediye bütçesi için hem zaman hem de maddi bir maliyettir. Alternatif maliyet bakış açısı ile yaklaşılan bir kamu harcaması harcamalarda verimliliği esas kılacaktır. Örneğin düğün salonlarını fonksiyonel inşa edebilseydik kamu harcamaları atıl kalmayabilirdi. Yılın belli günlerinde düğün olan salonları hem spor salonu olarak hem de çeşitli kursların verilebileceği (okçuluk, güreş, karete... vb.) bir salon olarak yapmak daha kullanışı hale getirebilirdi. Tabii süreç burada anlatıldığı gibi kolay olmayabilir, bu kursların buralarda verilebilmesi için Milli Eğitim Müdürlüğünden izin alınması gibi yasal gereklilikleri de beraberinde getirebilir...Bu anlamda yapılacak bir kamu harcamasının her zaman alternatif maliyeti düşünülmelidir." (K3). 
Bir diğer engel ise kamu kesimi ve özel kesim ayrımı katılımcı 9 tarafından katılımcı bütçe sürecinde olumsuz yön olarak değerlendirilmektedir.

"Belediye bütçe yapım sürecinde Manisa Büyükşehir Belediye meclisinde kamu yararı hususu göz önünde bulundurulmaktadır. 12 eylül meclis toplantısında henüz gündeme gelen bir konu vardı. Konu bir doğalgaz şirketinin kendi faaliyetleri konusunda yapmış olduğu bir kazı işleminden sonra açıkta kalan alanların asfaltlanması konusuydu. Özel bir doğalgaz şirketi belli bir mahallede doğalgaz döşeme işlemini gerçekleştirdikten sonra açıkta kalan ve üzeri asfaltlanmamış yollara asfaltı büyükşehir belediyesinin dökmesi hususunda talepte bulunmuştur. Öyle ki düşündüğümüzde kamu gelirleri vatandaşlardan tahsil edilir ve havuz sistemiyle tek bir yerde toplanır. Bizler kamu harcamaların değerlendirilmesinde söz sahibi olarak vatandaşların ödediği vergi ve benzeri ödemeleri özel sektörün yapması gereken ama yapılmasını büyükşehir belediyesinden talep ettiği bir kamu harcamasına yönlendirmek konusunda karar vericiyiz. İşte burada kamu yararı ya da kamu zararını iyi ölçüp tartmalıyız." (K9). Nitekim özel kesim, mal ve hizmetlerin bedellerini ödeyenlere hizmet sunarken kamu kesiminde bireysel değil toplumsal fayda söz konusudur. Bu açıdan örnekte ifade edildiği üzere hizmet sunumunda kamu kesimi ve özel kesim iç içe girebilmektedir.

Bir diğer husus ise Manisa Büyükşehir Belediyesi merkez ilçelerde vatandaş talebiyle gerçekleştirilen kamu projeleridir. Bunlar Tablo 10'da özetlenmiştir.

\section{Tablo 10.Manisa Büyükşehir Belediyesi Merkez İlçeler Vatandaş Katılımı Örnekleri}

\begin{tabular}{|l|l|}
\hline Şehzadeler Belediyesi & Yunusemre Belediyesi \\
\hline Kazım Karabekir Taziye Evi yapılmıştır. & $\begin{array}{l}\text { Yuntdağlarındaki mahallelere düğün salonu } \\
\text { talebi üzerine sosyal tesis yapılmıştır. }\end{array}$ \\
\hline $\begin{array}{l}\text { Ulucami Kamulaştırması halkın } \\
\% 70 \text { 'inin bu projede uzlaşması üzerine } \\
\text { gerçekleştirilecektir. }\end{array}$ & $\begin{array}{l}\text { Çalışan annelerin çocukları için kreş ve bakım } \\
\text { evleri yapılmıştır. }\end{array}$ \\
\hline $\begin{array}{l}\text { Ulupark Otopark Planı halkın itirazı } \\
\text { üzerine durdurulmuştur. }\end{array}$ & $\begin{array}{l}\text { Yuntdağı mahallelerinde tarıma ve çiftçiye } \\
\text { destek tohum, aşılama projeleri hayata } \\
\text { geçirilmiştir. }\end{array}$ \\
\hline $\begin{array}{l}\text { Uzunburun tesisi Saruhanlı'nın Develi } \\
\text { Mahallesinde halk tarafından } \\
\text { istenmemesi dolayısıyla orada yapımı } \\
\text { iptal edilmiştir. }\end{array}$ & $\begin{array}{l}\text { Muradiye kampüs için halk otobüslerinin } \\
\text { sayısı ve güzergah planının revize edilmiştir. }\end{array}$ \\
\hline $\begin{array}{l}\text { Manisa Büyükşehir Belediyesi } \\
\text { Manisa Büyükşehir Belediyesi kaldırım işgallerinden rahatsız olan halkın talebi üzerine } \\
\text { kaldırım işgalleri belediye tarafından önlenmiştir. }\end{array}$ \\
\hline
\end{tabular}


Tablo 10 incelendiğinde Manisa Büyükşehir Belediyesi ve merkez ilçe belediyelerinde vatandaş talebi üzerine gerçekleştirilen kamu hizmetleri olduğu görülmektedir. Özellikle her ilçe belediyesinin farklı ihtiyaçları olduğu dikkat çekmektedir. Merkez ilçeler olan Şehzadeler İlçe Belediyesi'nde Taziye evi, proje uzlaşması, otopark, katı atık tesisi gibi konularda vatandaş katılım örnekleri görülmektedir. Yunusemre ilç̧e Belediyesi'nde ise tarım ile ilgilenen mahallelere tohum desteği, düğün salonu, kreş ve bakım evleri, üniversite kampüs otobüsleri gibi konularda vatandaş katılım örnekleri görülmüştür. Manisa Büyükşehir Belediyesi örneğinde ise vatandaşların kaldırım işgallerine tepkisi üzerine belediye yönetiminin bu işgalleri önlendiği ifade edilmiştir.

\section{Sonuç}

Görüşme sonuçlarından elde edilen bulgular, çalışmada genel tema ve alt temalar açısından farklııı göstermiştir. Gerçekleştirilen görüşme araştırmasında anlaşıldığı üzere Manisa Merkez İlçeler Meclis Üyeleri'nin katılımcı bütçe konusunda net bilgiye sahip değildir. Kendilerine katılımcı bütçe kavramı açıklandıktan sonra katılımcı bütçe ve katılımcı yönetim ile ilgili örnekler sunabilmişlerdir. Bu açıdan görüşme sorularına göre sınıflandırılıp tablo haline getirilen katılımcı yanıtlarına bakıldığında vatandaş taleplerinin belli noktalarda katılımcı unsurlarla gerçekleştirildiği ifade edilmiştir.

Manisa merkez ilçelerde uygulanması düşünülecek bir katılımcı bütçe uygulaması için katılımcılar eğitim, vatandaş katılımının arttırılması ve proje oluşturulmasının önemini vurgulamışlardır. Manisa Büyükşehir Belediyesi Başkanının katılımcı bütçe uygulaması konusunda desteğinin önemli ve belirleyici olduğunu ifade etmişlerdir. Bununla birlikte katılımcı bütçenin tanıtımı, halkın bilgilendirilmesi ve bilinçlendirmesinin üzerinde durmuşlardır. Meclis üyeleri, katılımcı bütçe sürecinde gönüllü vatandaşlara destek olması açısından uzman kişilerden yardım alınmasını ifade etmişlerdir.

Manisa merkez ilçelerde pilot mahalle ya da pilot bir uygulama birimi seçilerek bu birimin lise, mahalle, üniversite olabileceğini ifade edilmişlerdir. Söz konusu pilot birimlerde katılımcı bütçeye dair tanıtım ve bilgilendirme toplantıları yapıldıktan sonra muhtar veya diğer ilgili gönüllü vatandaşlar ile birlikte katılımcı bütçenin gerçekleştirilmesi için harekete geçilmesi ifade edilmiştir. Kent demokrasisi adına güçlü sivil toplum kuruluşlarının önemi vurgulanmıştır. Manisa'da vatandaşlara sivil toplum algısının yerleştirilmesi için yerel yönetimler ve devlet destekli kamu spotları oluşturulmasının gereği vurgulanmıştır. Sivil toplum kuruluşlarının gönüllülük esasıyla kent adına yaptıkları çalışmalar katılımcı bütçe sürecinin en başından en sonuna kadar önemli olduğu vurgusu yapılmıştır.

Gönüllü katılımcılar, Manisa Büyükşehir Belediyesi merkez ilçelerde uygulanması düşünülecek katılımcı bütçenin kanunlara uygun gerçekleştirilmesinin 
önemini vurgulamışlardır. Kanunlara uygun olarak gerçekleştirilecek yenilikçi projeler Manisa ili pilot katılımcı bütçe uygulamasının kalıcılığını olumlu yönde etkileyeceği ifade edilmiştir.

Manisa'da küçük ya da büyük çaplı kamu projeleri daha önce düşünülmemiş ya da düşünülse de hayata geçirilmemiş olanları gerçekleştirerek hem Türkiye hem de dünya üzerinde ses getireceği vurgulanmıştır. Gönüllü katılımcılar tarafından üzerinde durulan nokta şudur ki; her kamu projesinin halk tarafından istişare edilemeyeceğidir. Nitekim belli projelerin uygulanması bazı vatandaşların avantajı olurken bazılarının dezavantajı olabilmektedir. Bu açıdan her projenin katılımcı bütçe konusu olamayacağı ifade edilmiştir.

Bu çalışmada, Manisa Büyükşehir Belediyesi Merkez Illçelerde resmi bir katılımcı bütçe uygulamasının gerçekleşmediği sonucuna varılmıştır. Manisa Merkez illçelerde vatandaş katılımı genelde sosyal doku ekibinin anket çalışmaları ve kent konseyi çalışmaları ile gerçekleşmektedir. Buna ek olarak, vatandaşların birebir meclis üyeleri ile görüşmesi, Manisa Beyaz Masa uygulaması, Manisa Büyükşehir Belediyesi çağrı merkezi, çözüm merkezi, vatandaşın muhtarlara ulaşması, Manisa Büyükşehir Belediye başkanı ve merkez ilçe başkanlarının mahalle ve muhtarlıklar ziyaretleri gibi uygulamalarla vatandaş taleplerinin belediye yönetimine iletildiği ifade edilmektedir. Manisa merkez ilçelerde uygulanması düşünülecek katılımcı bütçe için en uygun platformun bazı katılımcılar tarafından Manisa Kent Konsey'i olabileceği ifade edilmiştir. Katılımcılar, Manisa merkez ilçelerde vatandaşların sivil toplum algısının güçlendirilmesinin üzerinde durmuşlardır. Katılımcı bütçe uygulaması öncesinde yapılacak en önemli faaliyetin eğitim ve bilgilendirme olduğunu ifade etmişlerdir. Manisa'da katılımcı platformların canlandırılması gerektiğini ifade etmişlerdir.

\section{Kaynakça}

Alexa K. \& Eric M. (2017). Participatory Budgeting and Community Based Research:Principles, Parctices and Implications for Impact Validity, New Political Science, 39(1), http://www.tandfonline.com/doi/full/10.1080/07393148. 2017.1278857?src=recsys (15.04.2017).

Altunay, E, Oral G \& Yalçınkaya, M. (2014). Eğitim Kurumlarında Mobbing Uygulamalarına Illişkin Nitel Bir Araştırma, Sakarya Üniversitesi Journal of Education, 4(1), 62-80.

Avritzer, Leonardo (2000). Public Deliberation At The Local Level: Participatory Budgeting In Brazil, www.ssc.wisc.edu/ wright/avritzer.pdf. Yıldırım, Y (Ed). (2008. ) Porto Alegre- Fatsa: Yerel Düzeyde Demokrasiyi Demokratikleştirmek Çabaları Üzerine Bir Karşılaştırma., Ankara Üniversitesi Sosyal Bilimler Fakültesi Dergisi, 63(2), 273-287. 
Batırel, Ö.F. (1990). Kamu Bütçesi, İstanbul: Nihâd Sayar Yayın ve Yardım Vakfı Yayın No, 444-677.

Bayramoğlu, S. (2015). Toplumcu Belediye, Ankara: NotaBene Yayınları.

Community Development Project, A Research and Evaluation Report on Participatory Budgeting in New York City, "A People's Budget", www.participatorybudgeting.org (12.04.2017).

Çetinkaya, Ö. \& Korlu, R.K, (2012). Yerel Demokrasinin Sağlanmasında Katılımcılık Süreci ve Kent Konseylerinin Rolü, Maliye Dergisi, 163, 95-117.

Dülger, C. (2013). Bölgesel Kalkınmada Yeni Bir Anlayış PBUnit Yaklaşımı PBUnit Yaklaşımı Uygulama Sonuçlarının Yerel Katılımın Sağlanmasında Mali Saydamlık Açısından Değerlendirilmesi, KOP Bölgesi Üniversiteler Birliği Sempozyum Kitabı, 204-209, http://unikop.org/makale/KS13-3-14.pdf, (28.07.2018).

Ergen, Z. (2012). "Yönetimden Yönetişime: Katılımcı Bütçe Modeli", Maliye Dergisi, Sayı 163, Temmuz-Aralık 2012, ss. 316-334.

Falay, N. (2003). Devlet Bütçesi, Eskişehir: T.C. Anadolu Üniversitesi Yayını No:1513.

Fölscher, A. (2007), "Participatory Budgeting in Asia", Public Sector Governance and Accountability Series Participatory Budgeting edited vy Anwar Shah, The World Bank, www.worldbank.org (10.04.2017).

Johnson, C. (2017), Participatory Budgeting in New York, New York City Council, http://council.nyc.gov/pb/cycle-5-results/ (13.04.2017).

Keruwala, N. \& Maya Roy, K. (2017) "Participatory Budgeting in Pune", http://spa.ac.in/writereaddata/Session6bMrNaimKeruwalaArKomalPotdarand MsMayaRoy.pdf (13.04.2017).

National Foundation For İndia, "Budget Work İn İndia", http://www.nfi.org.in/ourprograms/local-governance/budget-work-india (20.05.2017).

Newyork City Council, "Participatory Budgeting", http://council.nyc.gov/pb/cycle-5results/ (05.05.2017).

Özen, A \& Yontar, I.G. (2009). Katılımcı Demokrasi Anlayışında Bütçeleme: Katılımcı Bütçeleme, Maliye Dergisi, 156, (Ocak-Haziran ), 280-293.

Participatory Budget, PMC, http://janwani.org/site/projects/participatory-budgeting2/ (10.04.2017).

Participedia, https://www.participedia.net/en/cases/pune-participatory-budgeting (14.04.2017).

Sakınç S. \& Aybarç Bursalıoğlu, S. (2014). Bütçelemede Demokratik Bir Değişim: Katılımcı Bütçeleme, Elecronic Journal of Vocational Colleges- May/ Mayıs, 4(1), 1-10. 
Shah, A. (2007). Participatory Budgeting, Public Sector Governance And Accountability Series, The World Bank, Brain Wampler(Ed). "Introduction to Participatory Budgeting".

Sanskriti M. \& Amarnath V. (2013), "Participatory Budget in Pune: A Critical Review",https://www.academia.edu/5217974/Participatory_Budgeting_in_Pun e_A_critical_review, (10.04.2017).

Santos, B.S. (1998). Participatory Budgeting in Porto Alegre: Toward a Redistributive Democracy, Polıtıcs \& Society, (26), December, 468-469.

Saunders, M. \& Lewis, P. \& Thornhill, A. "Research Methods For Business Students Fifth Edition", http://www.pearsoned.co.uk/ (19.09.2017).

Swarnim, W \& Shah, P, (2003). Social Development Notes, Porto Alegre, Brazil: Participatory Approaches in Budgeting and Public Expenditure Management . Draws on De Sousa Santos, (1998). Participatory Budgeting in Porto Alegre: Towards a Redistributive Democracy, Politics and Society (26), www.worldbank.org/participation, Note No 71, (29.07.2018).

TEPAV, İyi Yönetişim İçin Örnek Bir Model: Katılımcı Bütçe Raporu (2007). Türkiye Ekonomi Politikaları Araştırma Vakfı Yönetişim Etütleri Programı, www.tepav.org.tr (28.07.2018).

TÜBITAK, Bilgem YTE, Dijital Dönüşüm, https://www.dijitaldonusum.gov.tr/kararmekanizmalari/ (24.06.2018).

Ünver, G, Bümen, N.T \& Başbay, M. (2010). Ortaöğretim Alan Öğretmenliği Tezsiz Yüksek Lisans Derslerine Öğretim Elemanı Bakışı: Ege Üniversitesi Örneği, Eğitim Ve Bilim Dergisi, 35(155), 65-77.

Wampler, B. (2007). Participatory Budgeting in Brazil, Pennsylvania :The Pennsylvania State University Press University Park. 